\title{
Shut Away
}

by

Pearson Ripley

Bachelor of Science in Technical Photography

Appalachian State University, Boone, North Carolina, 2012

\author{
A Thesis presented to \\ Ryerson University
}

In partial fulfillment of the requirements of the degree of Master of Fine Arts

in the program of

Documentary Media

(C) Pearson Ripley

Toronto, Ontario, Canada, 2019 


\section{AUTHOR'S DECLARATION FOR ELECTRONIC SUBMISSION OF AN MRP}

I hereby declare that I am the sole author of this MRP. This is a true copy of the MRP, including any required final revisions. I authorize Ryerson University to lend this MRP to other institutions or individuals for the purpose of scholarly research. I further authorize Ryerson University to reproduce this MRP by photocopying or by other means, in total or in part, at the request of other institutions or individuals for the purpose of scholarly research. I understand that my MRP may be made electronically available to the public. 


\begin{abstract}
Shut Away is a window into a less-discussed immigration story in the United States. At present there are around fifty undocumented immigrants living in houses of worship after receiving deportation orders. It is the strategy of Immigration and Customs Enforcement (ICE) to avoid raiding these "sensitive locations," allowing them to provide their occupants with insulation from the possibility of deportation. This act of taking sanctuary comes at a significant cost as the individual does not leave the property upon entering. Comprised of still photographs, video portraits and oral histories, Shut Away seeks a more nuanced account of life in sanctuary beyond the common depiction of victimhood.
\end{abstract}

This paper will analyze the foundation, creation and context of the project. It begins with the historical and political background of the topic and the participants, then analyzes the methodology of the social and creative approach to the work. The paper ends with a contextualization of the project within the documentary field and a reflection on the traditions of photography in which the work falls. 


\section{Acknowledgements}

Foremost, I must express my unending gratitude to José, Juana and Samuel for their participation in the creation of the work. This project can only exist because of their daily resistance to injustice. I extend this thanks to their families who shared stories, concerns and hopes that informed the creation of these images. Thank you to Alerta Migratoria NC, for bringing me into sensitive spaces so I could better understand this work and for their tireless efforts in support of the undocumented community in North Carolina.

I must also thank the professors who helped me along the way: my supervisor Blake Fitzpatrick and my advisor Don Snyder whose knowledge of the form and critical eye helped guide my process; Sara Angelucci and everyone at the RIC for their help in organizing and installing the exhibition of the work; and Michèle Pearson Clarke and Deanna Bowen who gave me clarity at critical moments.

Finally, I thank my family for their love and support in all of my endeavors, and my friends and classmates for their companionship. This project constantly reminded me of the importance of being close to one's family and thankful for the support of one's friends. 
Table of Contents

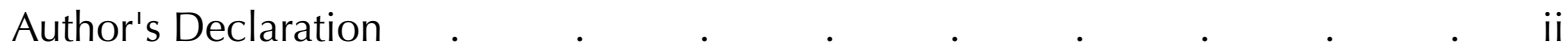

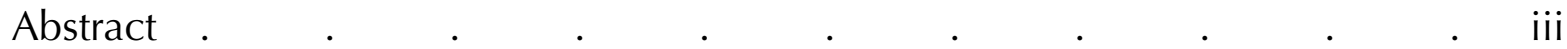

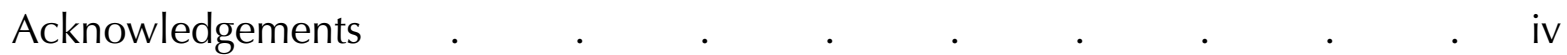

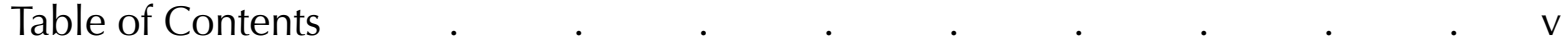

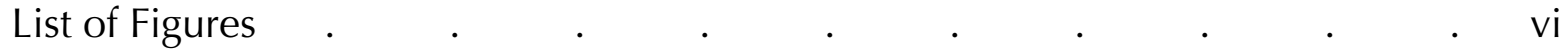

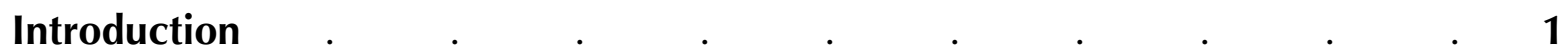

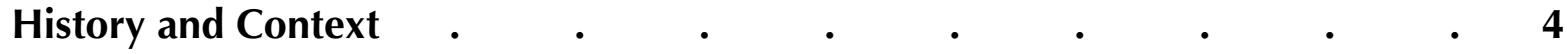

I. Mexican and Central American Immigration to the United States . $\quad 5$

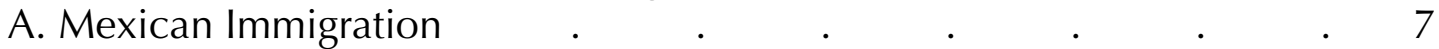

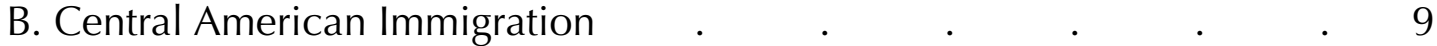

II. Immigration Politics in the United States $\quad$. $\quad$. $\quad$. $\quad$. $\quad$. 12

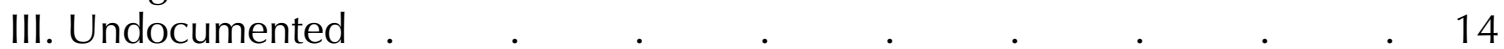

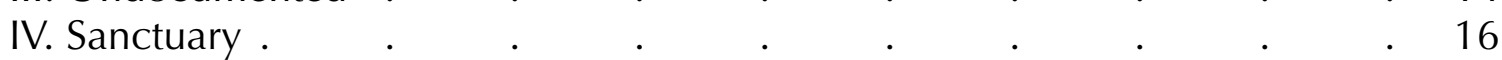

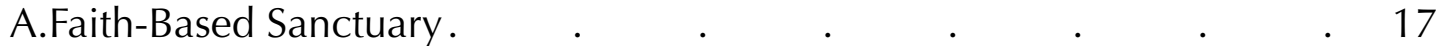

V. José, Juana and Samuel .

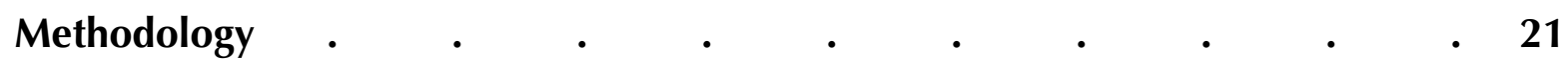

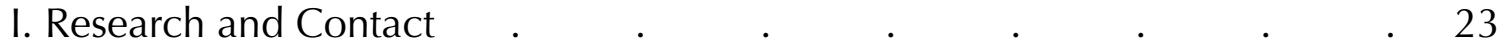

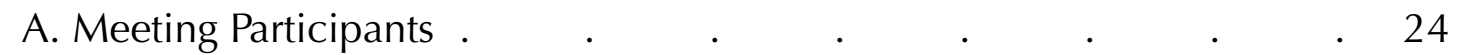

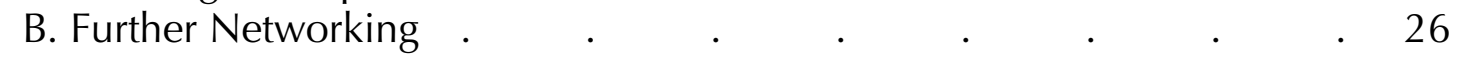

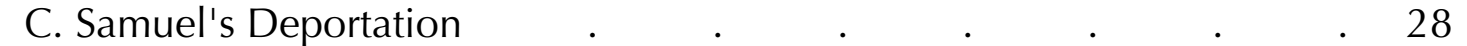

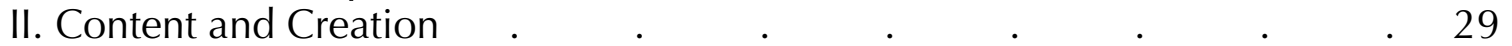

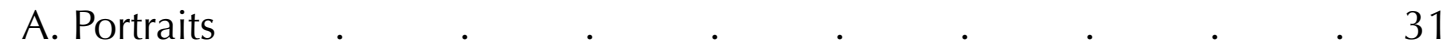

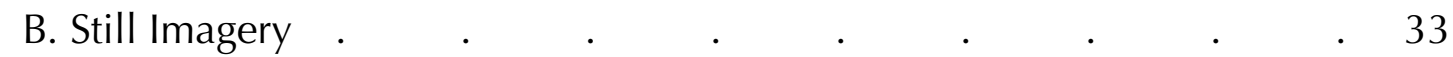

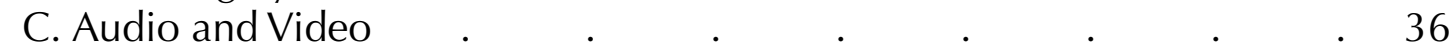

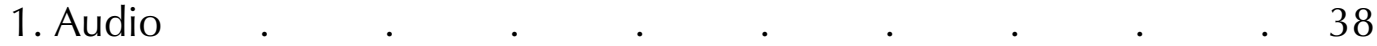

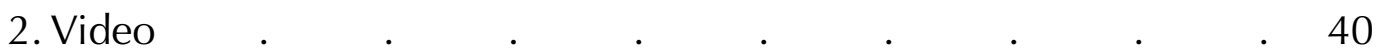

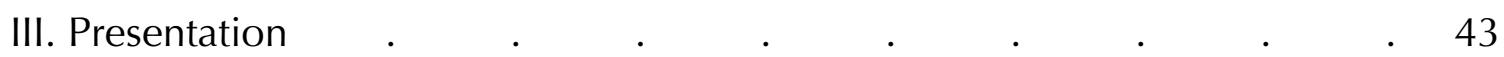

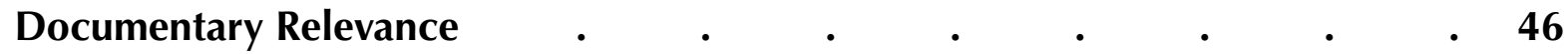

I. A Unique Representation of Immigration $\quad$. $\quad$. $\quad$. $\quad$. $\quad$. 48

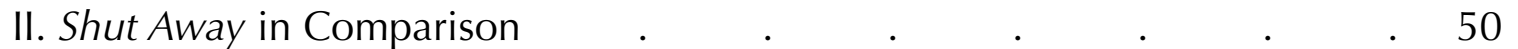

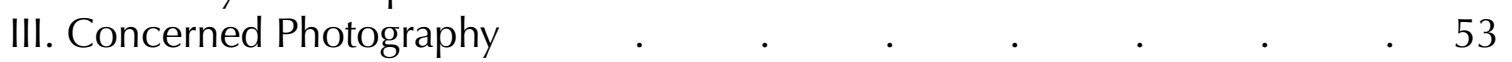

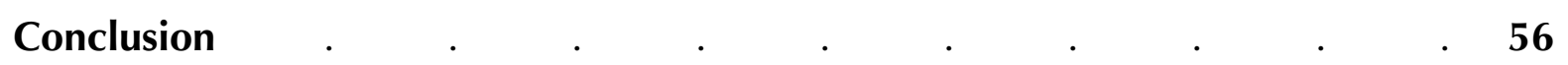

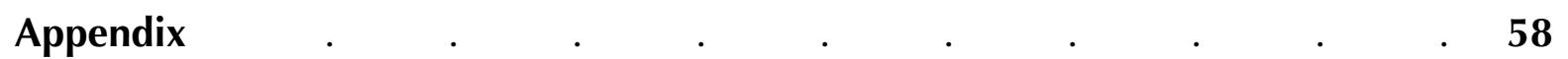

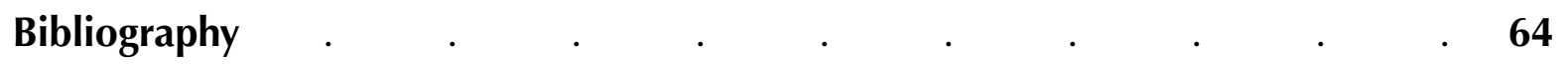




\section{List of Figures}

Figure 1. Samuel Oliver-Bruno

Figure 2. Juana Luz Tobar Ortega

Figure 3. José Heriberto Chicas

Figure 4. Symbolism I

Figure 5. Symbolism II

Figure 6. Inside v. Outside

Figure 7. Family Photographs

Figure 8. José Video Still

Figure 9. Juana Video Still

Figure 10. Samuel Video Still

Figure 11. Melanie Friend I

Figure 12. Melanie Friend II

Figure 13. Melanie Friend III

Figure 14. José Exterior

Figure 15. Samuel Exterior 
Encerrado/a - shut in, shut away, locked up. ${ }^{1}$

Shut Away - to put (someone or something) in a place that is separate from others. ${ }^{2}$

After spending many days over the course of several months in sanctuary churches, there was a word I heard in every conversation about the condition: encerrada or encerrado. The adjective translates to shut in, locked up or shut away. I considered which of these words most closely describes sanctuary's characteristics. In this context, sanctuary is the act of an undocumented person taking refuge in a house of worship, after receiving a federal deportation order. Despite an advancing nationalist immigration agenda, it remains the strategy of Immigration and Customs Enforcement (ICE) to avoid raiding "sensitive locations" including places of worship. 3 Seeking sanctuary in these churches provides some insulation from the possibility of deportation. It comes, however, at a significant mental, social and financial cost. When one enters sanctuary, they do not leave the property until their status changes. This can be weeks and months. It is often years; years of knowing that a trip to the corner store could cost you your family and community.

\footnotetext{
1 SpanishDict, s.v. "encerrado," accessed January 30, 2019, https://www.spanishdict.com/translate/encerrado.

2 Merriam-Webster, s.v. "shut away," accessed January 30, 2019, https://www.merriam-webster.com/dictionary/shut\%20away?utm_campaign=sd\&utm_medium=serp\& utm_source=jsonld.

3 John Morton, "Enforcement Actions at or Focused on Sensitive Locations," Rep. Enforcement Actions at or Focused on Sensitive Locations, Immigration and Customs Enforcement, https://www.ice.gov/doclib/ero-outreach/pdf/10029.2-policy.pdf, 1.
} 
Deportation has been known to cost deportees their lives. 4

In English, "locked up" has a specific meaning. It implies incarceration. Sanctuary is different. The doors to these cells have no lock or key. There are no physical barriers or armed guards preventing you from leaving, only the knowledge of what is at stake. Like unwilling recluses, these people have had to shut themselves away from their families, their communities and society. As I sat in these churches, the news media was alight with reports of family separation at the southern border. The people I sat with had been separated from their families as well. It just looked different. There were no cages or foil blankets in these churches. Nonetheless, they could not leave, or should not. And often, their families are not there.

As difficult as it is, they make this choice. The choice is to resist injustice and to be at least occasionally present for those they love. It is no small feat to stand up and resist the federal government of the United States of America. It is brave. This courage, however, manifests as conditions not typically associated with bravery: loneliness, uncertainty and boredom.

Shut Away focuses on three people in the state of North Carolina who, in defiance of their deportation orders, have left their homes and taken sanctuary. José Heriberto Chicas is an evangelical pastor who fled El Salvador during the civil war and had lived in Raleigh, NC, since the 1980s. He entered sanctuary in Durham, NC, in June of 2017. Juana Luz Tobar

\footnotetext{
4 Sarah Stillman, "When Deportation Is a Death Sentence." New Yorker, June 22, 2018, https://www.newyorker.com/magazine/2018/01/15/when-deportation-is-a-death-sentence.
} 
Ortega is a textile worker from Guatemala who came to Asheboro, NC, in the early 1990s after receiving death threats in her home country. She entered sanctuary in Greensboro, NC, in May of 2017. Samuel Oliver-Bruno is a construction worker from Mexico who had been living and working in Greenville, NC, for nearly 25 years. He entered sanctuary in Durham, NC, in December of 2017.

Using the still photograph, moving image, and spoken word, Shut Away explores this complex situation at the intersection of immigration, religion and politics. It shows the details of detention spaces and how they toe a fine line between homes and cells. Most importantly, it shows the nuanced individuality among stories that too often are dissolved into a single narrative. 


\section{History and Context}

In many cases, those who immigrate to the United States are fleeing conditions created by the country they seek to enter. Yet, it is frequently the desire of the US government to exclude them, even when they have legally justified asylum claims. The three individuals shown in Shut Away are unnecessary casualties of a nationalist trend in immigration policy that is spreading across the global north. In this section I will describe immigration history and policy in the United States, faith-based sanctuary and the realities of living without documentation. I will then introduce the three participants in my work: José, Juana and Samuel. 


\section{Mexican and Central American Immigration to the United States}

Since the 1970s, when discussing immigration in the United States, the first demographic that comes to mind is Latin American. When politicians, particularly conservatives, point to an immigration "problem", or presently a "crisis", it is Latinxs that they cite as its cause. ${ }^{5}$ By country of origin, the largest number of new arrivals in the United Sates has come from Mexico for several decades. ${ }^{6}$ Despite shifts in these trends, Latinxs remain the primary topic of discussion surrounding immigration. ${ }^{7}$ Part of this is due to the proportion of Latinx immigrants who are undocumented. In certain spheres, they also remain the primary target of unsubstantiated claims purposed for political fearmongering. ${ }^{8}$ Take Donald Trump's 2019 State of the Union speech, in which he outlined in grisly detail a series of murders allegedly committed by undocumented immigrants in the United States. ${ }^{9}$ This fearmongering was a mainstay of the conservative toolkit in the run-up to the 2018 midterm election. ${ }^{10}$ Latinxs are certainly not the only demographic unjustly vilified in this

\footnotetext{
5 Hector Amaya, "Trump and the Scapegoating of Latinos," From The Square, November 21, 2016, https://www.fromthesquare.org/trump-scapegoating-latinos/\#.XBLLkpNKjEY.

6 Abigail Geiger, "Key Findings about U.S. Immigrants," Pew Research Center, November 30, 2018, http://www.pewresearch.org/fact-tank/2018/11/30/key-findings-about-u-s-immigrants/.

7 "Latinx" is a gender-neutral and non-binary alternative to the masculine "Latino".

8 Steve Benen. "Trump Takes Anti-immigrant Fear-mongering to an Alarming New Level," MSNBC, June 25, 2018, http://www.msnbc.com/rachel-maddow-show/trump-takes-anti-immigrant-fear-mongering-alarming-newlevel.

9 Dara Lind, "Trump Has a Long History of Fearmongering about Immigrant Murder," Vox, February 05, 2019, https://www.vox.com/2019/2/5/18213077/state-of-the-union-2019-trump-david-killed-immigrant-family.

10 Michael D. Shear and Julia Hirschfeld Davis, "As Midterm Vote Nears, Trump Reprises a Favorite Message: Fear Immigrants," The New York Times, November 1, 2018, https://www.nytimes.com/2018/11/01/us/politics/trump-immigration.html.
} 
way. The distorted framing of Muslim immigrants as "terrorists" and the unconstitutional travel ban which was effected by executive order in 2017 are evidence of this. ${ }^{11}$ They just do not receive the same sustained intensity of scapegoating in politics and the media as Latinx immigrants.

Immigration from Mexico differs in its driving forces from that of the countries of the Northern Triangle of Central America (Guatemala, El Salvador, Honduras). ${ }^{12}$ Mexican immigration has largely been the result of several different periods of economic uncertainty stemming from various programs and policies on the part of the governments of the United States and Mexico. Immigration from the Northern Triangle, however, has mostly been a result of civil wars, whether it be the conflicts themselves or their violent fallout. There is, of course, an economic element to Central American immigration but this is tied directly to these wars. Mexico has also been facing an epidemic of organized crime-related homicides over the past 15 years. Regardless of which of these four countries one is emigrating out of, a higher quality of life is being sought, defined by a mixture of safety and economic prosperity.

\footnotetext{
11 Robert L. Tsai et al., "Trump's Travel Ban Faces Fresh Legal Jeopardy," POLITICO Magazine, March 27, 2019, https://www.politico.com/magazine/story/2019/03/27/trump-travel-ban-lawsuit-supreme-courtunconstitutional-226103.

12 Kate Brick, A. E. Challinor, and Marc R. Rosenblum, "Mexican and Central American Immigrants in the United States," Rep. Mexican and Central American Immigrants in the United States, Washington, DC: Migration Policy Institute, 2011, 3-4.
} 


\section{A. Mexican Immigration}

Mexican immigration to the United States began its rise during the mid-1940s with the introduction of the Bracero Program. ${ }^{13}$ Named after the Spanish word for manual laborer, the Bracero Program was initiated in 1942 as a bilateral agreement between the Mexican and US governments. It brought agricultural laborers to the United States while many of the nation's young men were fighting in World War II. ${ }^{14}$ Despite the program's termination in 1964, the need for agricultural labor in the United States spurred a steady climb in Mexican immigration. However, in 1982, Mexico's finance minster Jesús Silva-Herzog announced that Mexico would default on its sovereign debt and devalue the peso, leading to the Mexican debt crisis. 15 This caused a substantial rise in Mexican immigration into the United States. ${ }^{16}$

The Mexican immigrant population in the United States peaked in 2009, the year of the Great Recession. Since then, the population has been slowly decreasing. 17 This is due to several factors: increased border security making access more difficult, the economic

\footnotetext{
13 Fred L. Koestler, "BRACERO PROGRAM," The Handbook of Texas Online, Texas State Historical Association (TSHA), last modified June 12, 2010, https://tshaonline.org/handbook/online/articles/omb01.

14 The program established a minimum wage of thirty cents an hour and supposedly guaranteed decent living conditions for the workers. At its peak in 1956, the program employed over 445,000 workers.

15 "The Mexican 1982 Debt Crisis," RaboResearch - Economic Research, accessed December 13, 2018, https://economics.rabobank.com/publications/2013/september/the-mexican-1982-debt-crisis/.

16 As Mexico transitioned to a trade-oriented, capitalist system during the years that followed, this immigration would continue to rise.

17 Abigail Geiger, "Key Findings about U.S. Immigrants," Pew Research Center, November 30, 2018, http://www.pewresearch.org/fact-tank/2018/11/30/key-findings-about-u-s-immigrants/.
} 
recession in the United States, and a strengthening Mexican economy. 


\section{B. Central American Immigration}

As opposed to Mexican immigration, Central American immigration to the United States has been driven mainly by violent civil wars that occurred in those countries. Guatemala's civil war officially began in 1960. However, the events leading up to it began in 1954 when a US-backed coup d'etat overthrew the democratically elected, leftist government of Jacobo Árbenz and installed the right-wing military regime of Carlos Castillo Armas. ${ }^{18}$ The Árbenz government was pushing forward a decree which would redistribute arable land to the people of the country, threatening the economic interests of an American corporation, the United Fruit Company (UFCO). Under lobbying pressure from UFCO, President Truman authorized CIA Operation PBFORTUNE.19 Over the next forty-years Guatemala would be in turmoil, resulting in the deaths of over 200,000 civilians. Most of those deaths were indigenous Mayans who were targeted by genocide. ${ }^{20}$ Driven by economic and political interests, the war was escalated and sustained by foreign governments. ${ }^{21}$ Guatemala would be the first democratically elected government in Latin America to fall victim to one of the many cold war-era proxy wars that would change global politics

18 Nicholas Cullather, Operation PBSUCCESS: the United States and Guatemala, 1952-1954, (Washington, DC: History Staff, Center for the Study of Intelligence, Central Intelligence Agency, 1994), 24.

19 This operation supplied arms to the far-right military dictatorship, executed B-26 bombing runs using equipment disguised as Guatemalan government planes, and other military actions.

20 "Timeline: Guatemala's Brutal Civil War," PBS, last modified March 7, 2011, https://www.pbs.org/newshour/health/latin_america-jan-june11-timeline_03-07.

21 Backing the right-wing dictatorship were the United States and Argentina. Israel, apartheid South Africa and Taiwan supplied logistical support. Backing the left-wing communists were Cuba, Nicaragua and the Soviet Union (until its dissolution in 1990). 
permanently.22 Despite the signing of a peace accord in 1996, the violent fallout from the war would keep Guatemala's homicide rate as one of the highest in the world. ${ }^{23}$

Like the Guatemalan Civil War, the Salvadoran Civil War could never have escalated into the catastrophe that it was without foreign intervention. Fearing the rise of communism in the country, the administration of President Jimmy Carter supported the Revolutionary Government Junta of El Salvador (JRG). ${ }^{24}$ During the Carter and Reagan years, the US would spend $\$ 1$ million per day on military support to the violent dictatorship in their war against the left-wing Farabundo Martí National Liberation Front (FMLN). By the end of his first term, Reagan alone had authorized over $\$ 1$ billion in military aid. ${ }^{25}$ During the course of the twelve-year war, 80,000 Salvadorans would be killed and over one million people, twenty-percent of the population, would be displaced. ${ }^{26}$ As in Guatemala, the aftermath of war would create a culture of violence in El Salvador that continues to the present.

\footnotetext{
22 These Unites States/Russia proxy wars have not been limited to the Cold War era. Among them are wars in Angola, East Timor, Afghanistan, Syria and more. As of April 2019, we are seeing a potential proxy war beginning to develop in Venezuela as well.

23 Rocio Cara Labrador, and Danielle Renwick, "Central America's Violent Northern Triangle," Council on Foreign Relations, accessed December 13, 2018, https://www.cfr.org/backgrounder/central-americas-violent-northern-triangle.

24 Donald R. Hamilton, "El Salvador in the 1980s: War by Other Means," CIWAG Case Studies, June, 2015, http://digital-commons.usnwc.edu/ciwag-case-studies/5, 12.

25 Kevin Sullivan, and Mary Jordan, "In Central America, Reagan Remains A Polarizing Figure," The Washington Post, June 10, 2004, http://www.washingtonpost.com/wp-dyn/articles/A29546-2004Jun9.html.

26 This also created a disastrous refugee crisis in Honduras which has had lasting effects on the country. In the United States, The Immigration Act of 1990 would establish Temporary Protective Status (TPS) to Salvadorans seeking asylum. TPS is a program designed to prevent deportation back to countries which, for reasons of war or natural disaster, are deemed too unsafe. Until its cancellation in 2018, TPS would provide a legal avenue of residency for Salvadorans in the United States.
} 
Interventions by foreign powers, civil war, narcotics trafficking, and gang violence have made the countries of the Northern Triangle the most dangerous in the world that are not currently engulfed in war. ${ }^{27}$ This has resulted in a massive increase in immigration to the United States from the Northern Triangle countries over the past several decades. ${ }^{28}$ Today, rates of immigration from the Northern Triangle are steadily rising and neither global economics nor climate science predicts a reversal of this trend in the future. ${ }^{29}$

27 United Nations, "Intentional Homicide Victims | Statistics and Data," United Nations, accessed December 13, 2018, https://dataunodc.un.org/crime/intentional-homicide-victims.

28 According to the Pew Research Center, immigration to the United States from these countries has tripled since 1990.

29 D’Vera Cohn, Jeffrey S. Passel, and Ana Gonzalez-Barrera, "Immigration From Guatemala, Honduras, El Salvador Up," Hispanic Trends Project, June 04, 2018, https://www.pewhispanic.org/2017/12/07/rise-in-u-s-immigrants-from-el-salvador-guatemala-and-hondurasoutpaces-growth-from-elsewhere/. 


\section{Immigration Politics in the US}

Immigration policy in the United States is complex, discriminatory and, I would argue, usually punitive. ${ }^{30}$ It falls under a rule referred to as the plenary power doctrine. ${ }^{31}$ The doctrine can be defined more as a tradition of judicial deference than as a policy or rule. It has been the general custom of US courts, with some exceptions, to defer court cases relating to immigration back to the political branches. ${ }^{32}$ For immigrants, the result of this doctrine is uncertainty as new elections can have dramatic results on the enforcement of immigration law.

Immigration legislation has been notoriously hard to pass for many years and since the enforcement of immigration law is up to the executive branch, changing administrations have a disproportionately high effect on undocumented immigrants. ${ }^{33}$ With the transition into the Trump administration, deportations dropped; 2017 saw fewer deportations than any year during the Obama administration. This, however, can also be explained by a

\footnotetext{
30 This is the author's assertion and is opposed to the beliefs of the US government. The US Supreme Court has ruled that exclusion and deportation are not punishments, they are administrative proceedings. This means that, not being considered punishment in the form of deprivation of life, liberty, or the pursuit of happiness, do not warrant due process. In a 1953 court case, this was extended to assert that even in the case of indefinite detention, the immigrant is not entitled to due process.

31 John Feere, "Plenary Power: Should Judges Control U.S. Immigration Policy?," Center for Immigration Studies, last modified February 25, 2009, https://www.cis.org/Report/Plenary-Power-Should-Judges-Control-US-Immigration-Policy.

32 The political branches are the executive branch (the President) and the legislative branch (Congress).

33 The topic is one of the most divisive in US politics and legislators are hesitant to compromise on bills related to the issue for fear of displeasing voters. It is also frequently used as a bargaining chip in Congress. A path to citizenship for DACA (Deferred Action for Childhood Arrivals) recipients, for example, would not be brought to the floor by Senate Majority Leader Mitch McConnell (R-KY), except when attached to a bill promising $\$ 25$ billion for a border wall and massive increases in border security spending.
} 
dramatic decrease in attempts to enter at the southern border since many deportations happen there..$^{34}$ Interior immigration enforcement has risen during the Trump administration with ICE arrests and deportations up significantly. The new immigration policies adopted by the Trump administration give little consideration to criminal records or extraordinary circumstances. 35

This short summary barely scratches the surface of one of the most complex areas of US politics. It does, though, explain why certain communities can be so highly affected by a changing administration. It is commonly believed that the President has little power compared to other branches of government. Typically, the President's powers can be easily checked by another branch. There are, however, certain arenas in which the executive branch operates with sole authority. Immigration enforcement is one of those. That is why 2017 brought such a dramatic change to the lives of undocumented immigrants.

\footnotetext{
34 Dara Lind, "Family Separation Was New, but Trump's New Border Policy Is an Obama Throwback," Vox, June 21, 2018, https://www.vox.com/2018/6/21/17488458/obama-immigration-policy-family-separation-border.

35 Nick Gass et al., "Trump's Immigration Plan: Mass Deportation," POLITICO, August 17, 2015, https://www.politico.com/story/2015/08/donald-trump-immigration-plan-121420.
} 


\section{Undocumented}

10.7 million people live in the United States without papers. ${ }^{36}$ There are many reasons why an individual might choose to, or be forced to, remain undocumented. Immigrants often receive substandard legal advice from inexpert or negligent attorneys after crossing into the United States. Other times those who have received federal charges for "illegal reentry" or have been convicted of a different crime have no choice but to remain undocumented, regardless of the nature or severity of the charge. 37 Additionally, only about 28 percent of asylum claims are granted, with the rate of acceptance varying from 10 to 80 percent across different immigration courts. ${ }^{38}$ This means that the other 72 percent will be forced to remain undocumented, should they stay in the United States. Life without papers is difficult. Any interaction with authority is undesirable and could result in deportation. Because of this, undocumented immigrants avoid calling emergency services even when the need is dire. This is particularly problematic when considering issues of domestic violence. It is legal for ICE to make arrests at courthouses. Knowing this, undocumented women are hesitant to press charges against an abuser for fear of being

\footnotetext{
36 Jeffrey S. Passel, and D'Vera Cohn, " U.S. Unauthorized Immigrant Total Dips to Lowest Level in a Decade," Rep. U.S. Unauthorized Immigrant Total Dips to Lowest Level in a Decade, Pew Research Center, 2018, file:///Users/pearsonripley/Downloads/Pew-Research-Center_U-S-Unauthorized-Immigrants-Total Dips_2018-11-27.pdf, 3.

37 United States, "1912. 8 U.S.C. 1326 -- Reentry After Deportation (Removal)," Department of Justice, 2018, accessed September 19, 2018, https://www.justice.gov/jm/criminal-resource-manual-1912-8-usc-1326-reentry-after-deportation-removal.

38 Zuzana Cepla, "Fact Sheet: U.S. Asylum Process," National Immigration Forum, January 10, 2019, https://immigrationforum.org/article/fact-sheet-u-s-asylum-process/.
} 
arrested while attending required judicial proceedings. 39 These are just a few of the numerous reasons for and results of remaining undocumented.

Approximately three percent of the United States population is undocumented. ${ }^{40}$ North Carolina has the seventh-highest population of undocumented people in the country, with a percentage higher than the national average. Six percent of California's population is undocumented, the highest of any state. On March 26, 2018, Commerce Secretary Wilbur Ross announced the planned addition of a question to the 2020 census: "Is this person a citizen of the United States?" 41 By adding this question to the census, the administration is attempting to further cull the voices of undocumented Americans. The goal, regardless of what the administration claims, is to keep undocumented people from participating in the census. This means fewer congressional seats for the areas where they live, less representation and therefore less power. If none of California's undocumented population participated in the census, the state could lose four seats in Congress.

\footnotetext{
39 Jennifer Medina, "Too Scared to Report Sexual Abuse. The Fear: Deportation," The New York Times, April 30, 2017, https://www.nytimes.com/2017/04/30/us/immigrants-deportation-sexual-abuse.html.

40 Passel and Cohn, "U.S. Unauthorized Immigrant Total," 3.

41 Amelia Thomson-DeVeaux, "How The Citizenship Question Could Break The Census," FiveThirtyEight, April 23, 2019,

https://fivethirtyeight.com/features/how-the-citizenship-question-could-break-the-census/.
} 


\section{Sanctuary}

Sanctuary has a varied meaning in the United States. Most commonly, sanctuary refers to the adoption of certain laws by a state, county or municipality that protects the rights of immigrants within that jurisdiction. 42 There are a variety of different policies that can apply to these cases. The most common policy that accompanies sanctuary status is a refusal on the part of law enforcement agencies to cooperate with ICE on deportation operations. It is this action that leads to the label of "sanctuary city" or "sanctuary state." 43 According to an ICE report in 2017, twenty-four states and the District of Columbia have sanctuary municipalities. ${ }^{44}$ The type of sanctuary being explored in Shut Away, however, is quite different.

42 Dara Lind, "Sanctuary Cities, Explained," Vox, March 8, 2018, https://www.vox.com/policy-and-politics/2018/3/8/17091984/sanctuary-cities-city-state-illegal-immigrationsessions.

43 This does not, however, prohibit ICE from carrying out operations in these areas. In July of 2018, 197 undocumented immigrants were arrested during operations in New York City and Washington, D.C, both of which are labeled sanctuary municipalities.

44 Raphael, T. J., "'Sanctuary Cities' around the US Promise to Defy Trump's Threats," PII, November 15, 2016, https://www.pri.org/stories/2016-11-15/sanctuary-cities-around-us-promise-defy-trumps-threats. 


\section{A. Faith-based Sanctuary}

This project refers to faith-based sanctuary which is the act of an immigrant who is facing deportation taking refuge in a house of worship. Historically, the movement began in the 1980s, when immigration from the Northern Triangle soared as civil war and displacement rocked the small nations. The movement is believed to have begun in Tucson, Arizona. ${ }^{45}$ The modern policy on which the sanctuary movement is based was established in a memorandum issued by ICE director John Morton on October 24, 2011. In reference to ICE arrests, interviews, searches and surveillance, it states that, "This policy is designed to ensure that these enforcement actions do not occur at nor are focused on sensitive locations such as schools and churches." 46 Later, it extends religious locations to "churches, synagogues, mosques or other institutions of worship, such as buildings rented for the purpose of religious services..." 47 The sensitive locations policy also includes schools, hospitals, weddings, funerals and public gatherings such as protests, parades, etc. Although there is no modern instance of ICE entering a sanctuary church in order to make an arrest, there is no law binding the agency to follow this policy.

As of June 2019, there are over fifty immigrants that have taken refuge in churches across

\footnotetext{
45 Lane Van Ham, "Sanctuary Revisited: Central American Refugee Assistance in the History of ChurchBased Immigrant Advocacy," Political Theology 10, no. 4 (2009): 621-45, https://doi.org/10.1558/poth.v10i4, 621.

46 John Morton, "Enforcement Actions at or Focused on Sensitive Locations," Rep. Enforcement Actions at or Focused on Sensitive Locations, Immigration and Customs Enforcement, https://www.ice.gov/doclib/ero-outreach/pdf/10029.2-policy.pdf, 1.

47 John Morton, "Enforcement Actions," 1.
} 
the country. 48 This number is in constant flux as cases are litigated. ${ }^{49}$ Sanctuary is not a solution. It can buy the individual some time but often is a last resort after all legal options have been exhausted. Occasionally, sanctuary provides the immigrant with the extra few months they need to finish fighting an active immigration or asylum case. They then receive a stay of deportation and can leave the church. More commonly, the individual waits with uncertainty, hoping for policies to change. This is the case with the three participants in Shut Away.

48 Bill Rodgers, "More Undocumented Immigrants Are Living in US Sanctuary Churches," VOA, January 29, 2019, https://www.voanews.com/a/more-undocumented-immigrants-are-living-in-us-sanctuary-churches-/ 4763198.html.

49 As of December 2018, there are four public cases of sanctuary in North Carolina. This number had been six as of summer 2018. One man's case for deferment was settled in his favor and Samuel Oliver-Bruno was arrested and deported back to Mexico. 


\section{José, Juana and Samuel}

José Heriberto Chicas, Juana Luz Tobar Ortega and Samuel Oliver-Bruno are the three participants in Shut Away. They are from El Salvador, Guatemala and Mexico respectively, and all were issued deportation orders in 2017. José and Juana fled civil wars in their countries and Samuel came to the United States for economic reasons. All three have children who are American citizens, and spouses who are either citizens or permanent residents. Each of their cases is different.

José fled El Salvador in 1985 while the civil war was at its peak. He had been living in the United States for 32 years at the time his deportation order was issued. José is married with four children, three of whom are citizens. The fourth is a recipient of Deferred Action for Childhood Arrivals (DACA). ${ }^{50}$ The DACA program prevents the deportation of millions of undocumented Americans, often referred to as Dreamers, who were brought to the country as children. As of June 2019, José has spent 24 months in sanctuary in Durham, NC.

Juana also fled civil war in Guatemala in the early 1990s. She lived in California for several years before moving to North Carolina. She had been living and working in the United States for 26 years at the time she was issued a deportation order. Juana's husband is an American citizen. She has two children who are recipients of DACA and two who are

\footnotetext{
50 United States, "Consideration of Deferred Action for Childhood Arrivals (DACA)," Department of Homeland Security, accessed December 14, 2018, https://www.uscis.gov/archive/consideration-deferred-action-childhood-arrivals-daca.
} 
citizens. She also has two granddaughters. As of June 2019, Juana has spent 25 months in sanctuary in Greensboro, NC.

Samuel moved from Veracruz, Mexico, to North Carolina in 1995 when he was 23 years old. He was seeking economic prosperity. He met his wife in the United States and their only child was born in 1999. Samuel was issued a deportation order at 46, after spending half of his life in the United States. As of November 2018, Samuel had spent 11 months in sanctuary. 51

José, Juana and Samuel are the main subjects in Shut Away. They each come from a different country, had a different reason for coming to the United States and have distinct differences in their immigration cases. They are bound, though, by the injustice they are facing and the fight to remain with their families. The experience of living in sanctuary can be viewed through their stories in a way that would not be possible with just one individual. Millions of people from each of their countries are living in the United States and came here for the same reasons they have. While their current struggles to stay are unique, their experiences leading up to sanctuary can be seen in the stories of immigrants all across the nation. This makes them ideal participants in a documentary project that aims to show exceptional stories within a commonplace issue. That issue, immigration, is one that is relevant not only to our continent but to the world as a whole; along with and because of a changing climate, it will be the defining issue of our time. ${ }^{52}$

51 On November 23, 2018 Samuel was arrested and deported by ICE.

52 Laura Parker, "143 Million People May Soon Become Climate Migrants," National Geographic, March 19, 2018, https://news.nationalgeographic.com/2018/03/climate-migrants-report-world-bank-spd/. 


\section{Methodology}

This project was my first documentary work of this scale and duration. I learned an immense amount as it progressed and my style of photography seemed to change on a weekly basis. It was the social aspect of the work that was the most demanding. Reflecting on the process of this project, I would say two-thirds of my documentary effort is social. The research, telephone calls, outreach, and presence at events and with participants are all essential aspects of the form.

There was also a constant consideration of my positionality relative to my participants. As a white storyteller working with people of color in vulnerable situations, a keen awareness of the inherent power dynamics was essential in both my social presence as well as the formal execution of the work. As Linda Alcoff states in her influential essay The Problem of Speaking for Others, "...a speaker's location... has an epistemically significant impact on that speaker's claims and can serve either to authorize or disauthorize one's speech." 53 She continues to say, "In particular the practice of privileged persons speaking for or on behalf of less privileged persons has actually resulted (in many cases) in increasing or reinforcing the oppression of the group spoken for." ${ }^{54}$ Seeking a balance between my voice as a creator and the voices of my participants was critical to producing a successful project. Furthermore, a knowledge of the existing narratives about undocumented immigrants and their effects was necessary in order to avoid reinforcing them. I will expand on this

\footnotetext{
53 Linda Alcoff, "The Problem of Speaking for Others," Cultural Critique, no. 20, (1991): 5-32, doi: 10.2307/1354221, 7.

54 Alcoff, "The Problem of Speaking for Others," 7.
} 
throughout the explanation of my methodology.

In order to best explain my process, I will break this section into several parts. I will start by explaining my research and outreach for the project. Following that will be an analysis of its creation, including both social and creative commentary. Finally, I will discuss my approach to the presentation of Shut Away. 


\section{Research and Contact}

Around 2013, I began to take notice of news media that described cases of sanctuary across the United States. These stories are often covered by local news but are rarely prioritized by national outlets. There are a few independent national news sources that cover these stories, including Democracy Now!, where I first heard of faith-based sanctuary. ${ }^{55}$ It could be said that, informally, my research started at this point. Over the following years I collected news stories about sanctuary and did shallow research into its history. This research continued when I began the Documentary Media program in September of 2017. In May, I made the decision to pursue the topic of faith-based sanctuary in North Carolina. It was at this time that I began both deep research into the topic, as well as outreach. I began cold-calling the sanctuary programs at various churches around my hometown, which is in the Triangle area of central North Carolina. Within a few days I had several calls returned. One of them was from Jonathan Wilson-Hartgrove, coordinator of the School for Conversion, a small educational ministry in Durham, NC. José Chicas, an undocumented man from El Salvador, had been living in the school for almost a year. Wilson-Hartgrove gave me Chicas' telephone number and told me he would let him know I would be calling. Several days later I called José. During the call, I described my plan for the project and purpose in pursuing the topic. José immediately expressed interest and we made a plan for our first meeting.

\footnotetext{
55 Amy Goodman, "Mexican Immigrant Takes Refugee in Arizona Church," Democracy Now!, May 15, 2014, https://www.democracynow.org/2014/5/15/headlines/mexican_immigrant_takes_refugee_in_arizona_church.
} 


\section{A. Meeting Participants}

I returned to North Carolina several weeks later. The day after I arrived, I drove to Durham to meet José for the first time. The sanctuary where he had been living was a small house in a residential neighborhood. It is an educational ministry on the property of a Baptist church and therefore is considered a house of worship. He greeted me at the door and we sat down at the dining room table. I told him a bit about myself. He then told me his story.

He started with his childhood, described growing up in El Salvador during the civil war, detailed his journey to the United States and told me about the life he had led since. We then talked about his life since entering sanctuary and the political climate that had put him there. My first meetings with participants were intense experiences. For one, we could communicate only in Spanish. I speak well, but it is not my first language and I cannot speak and hear with the casual fluency of someone raised bilingual. On top of this, the stories oscillated mostly between downcast and tragic. I had to be an acute listener as I needed to comprehend perfectly. I opted not to use a voice recorder as I did not want to establish our relationship as strictly journalistic. I would write notes, though, when I heard important topics so they could be raised during our recorded interviews. When statements were made that I did not understand, I would ask José to clarify, which he never seemed to mind.

My second visit marked one year since José had entered sanctuary. It was not until my fourth visit that I brought my camera. That day we walked around the property and took 
some photographs. He carried his bible with him and posed for me in various places around the property. It was clear he had done this many times with journalists. These were not the type of images that I would ever use in a project, but it helped open the way for a creative relationship. I believe that, when possible, it is always best to meet the people that I will be working with before taking pictures. I find that a camera often hinders the establishment of a genuine connection. As a cultural outsider in these spaces, I felt that I needed to make clear that I did not intend to arrive, take what I needed and leave. I wanted to spend as much time there as they would allow me in order to comprehend the situation as thoroughly as possible. Throughout the project I spent most of my time listening. To quote Alcoff once again, "If one's immediate impulse is to teach rather than listen to a less-privileged speaker, one should resist that impulse long enough to interrogate it carefully." 56 From the outset, I made it clear that I was there in an attempt to understand, but with full awareness that it was not the duty of my participants to teach me anything.

This is approximately how all of my relationships with my participants began. Creating a project this way involves a sizable investment of time and by not always recording, I surely missed important images and information. I believe, though, that those initial days of conversation without the pressure of recording devices were invaluable in the establishment of the friendship that has resulted.

\footnotetext{
56 Linda Alcoff, "The Problem of Speaking for Others," Cultural Critique, no. 20, (1991): 5-32, doi: 10.2307/1354221, 24.
} 


\section{B. Networking}

Several weeks after my return to North Carolina, I received a return call from the sanctuary coordinator at one of the other churches I had initially contacted. The church was Citywell Methodist, also in Durham, and a man named Samuel Oliver-Bruno had been living there for six months. I sent the coordinator a sample of the work I had been doing with José and we arranged a time for me to come meet Samuel. Just as I had done with José, I explained what I was doing and why. He then told me his story and we made a plan for me to come back several days later.

About a month into the summer, I connected with Alerta Migratoria, an immigrant's rights organization operating out of Durham. ${ }^{57}$ Over the course of several days, Alerta's coordinator and I drove around central North Carolina visiting each of the six people living in churches. This was an important opportunity. It allowed me to spend a full day driving around with an activist full of knowledge about sanctuary and immigration politics. I also was able to meet several other people that were living in sanctuary. During our drive, she informed me of a summit that would be happening in Durham the following week. During this summit, people in sanctuary all over North Carolina as well as those in Ohio, Texas and Colorado would leave their sanctuaries in secret and travel to Durham. There, they would learn activism strategies that would assist them in fighting their

57 Alerta Migratoria NC, "About," Alerta Migratoria NC, accessed April 08, 2019, http://alertamigratoria.org/about/. 
immigration cases. I expressed my interest in attending, and was given the details. 58

Attending this summit allowed me to learn about activism strategies within the community and to meet and network with those within the sanctuary realm. It was also where I met Juana and where we planned for me to come visit her sanctuary church in Greensboro. During the summer I also attended a protest for the people living in sanctuary that was staged at a town hall meeting with David Price, the district's US congressman. ${ }^{59}$ For each event, I would send a batch of edited images to Alerta for use in their various channels. I believe that when making political documentary, it is important to engage with the activist side of the topic as well. Practically, it's a great way to meet people connected to the issue. Philosophically, it's an investment of time and emotion into the topic being explored. Personally, it helps me to connect with my creative work on a deeper level.

\footnotetext{
58 The summit occurred partially at Citywell Methodist in Durham, the church where Samuel had been living. That morning those attending the summit who were living in sanctuary told the stories of their lives. They were stories of war, struggle and injustice; family, happiness and perseverance. The morning was intense and emotional. After lunch, the summit moved to a different location in the city. The rest of the weekend was spent learning how to organize and utilize what power they had to advance their causes.

59 Joel Brown, "Immigration Activists Interrupt Rep. Price's Raleigh Town Hall," ABC11 Raleigh-Durham, July 20, 2018,

https://abc11.com/immigration-activists-interrupt-rep-prices-raleigh-town-hall/3791260/.
} 


\section{The Deportation of Samuel}

On November 23rd, 2018, Samuel visited one of the offices of the United States Citizenship and Immigration Services (USCIS). This is a separate agency from ICE but is also under the umbrella of the Department of Homeland Security. USCIS had informed Samuel that, although still active, his case could not be advanced without a biometrics screening. ${ }^{60}$ Samuel made a difficult choice to leave his sanctuary and complete this request, in hopes that his case could move forward. He was accompanied to the appointment by many supporters and his family, but after twenty minutes in the waiting room, ICE agents appeared from behind the front desk and arrested him.

In the week that followed, Samuel was moved daily from local to state and then regional detention centers. He was deprived of proper meals and his medication. Finally, Samuel was brought over the southern border by ICE agents and left in Northern Mexico. Seven months later, he remains there.

Supporters live streamed the event on Facebook and I watched it unfold from my apartment in Toronto. I felt powerless and wished I could have been there to support him. The way I experienced this injustice was mediated, but still affected me deeply. The event reminded me of why I consider it important to be present and emotionally invested in the activism surrounding a project.

\footnotetext{
60 Tina Vasquez, "Samuel Oliver-Bruno, Deported After an Immigration Appointment, in His Own Words," Rewire.News, December 14, 2018, https://rewire.news/article/2018/12/14/samuel-oliver-bruno-deported-after-an-immigration-appointment-inhis-own-words/.
} 


\section{Content and Creation}

Shut Away is comprised of three distinct parts: the portraits, the still imagery, and the video installation. All were made to feel visually cohesive, but they are meant to accomplish distinct goals. The portraits are intended to bring an air of strength and dignity to the participants in the project. They are crucial in bringing clarity to the identities of José, Juana and Samuel and are meant to be declarations of their individuality. The still imagery is an attempt at communicating the greater experience of sanctuary and is where the main themes of the work are most evident. The video installation brings the voice of the participant into the project and, in the case of the exhibition, into the viewing space. It allows the audience to hear the histories and opinions of the person living in sanctuary in a direct manner, and is purposed to bring specificity to the story of each individual.

There are several creative themes central to the project that arise repeatedly during the work. These themes are confinement and enclosure; separation and isolation; and the dichotomy of inside and outside. Through my shooting style and editing choices, I tried to convey these ideas to the viewers. This included tightly framed images to impart feelings of claustrophobia and confinement (See Appendix, Figure 5). Pictures of family photographs and wide, empty images show separation and loneliness. The consistent depiction of windows in the images as well as "life" inside, as shown through plants, flowers and trees speaks to the dichotomy of in against out. The themes above were repeatedly

communicated to me by my participants as overbearing sensations of life in sanctuary. 
The still imagery is the medium through which I established my voice as a storyteller. The images are often tightly cropped and focus on specific details. I intentionally selected the more subjective images from the project for display in the gallery. I used the video installation in the exhibition as a way to bring the voice of my participants into the work and create a balance between our perspectives. I needed, though, to avoid overwhelming my creative voice in the process. As Bill Nichols states in The Voice of Documentary,

Far too many contemporary film-makers appear to have lost their voice. Politically, they forfeit their own voice for that of others (usually characters recruited to the film and interviewed). Formally, they disavow the complexities of voice, and discourse, for the apparent simplicities of faithful observation or respectful representation, the treacherous simplicities of an unquestioned empiricism. The world and its truths exist; they need only be dusted off and reported. 61

I believe that through this intentional avoidance of false objectivity in the images, my opinions as a storyteller can be perceived. Additionally, the utilization of the affect-related advantages of the literal voice of my participants was, in itself, an assertion of my creative presence. In this composition I attempted to approach an equilibrium in our perspectives. In the following section I will discuss my reasoning for this balance as I explain each component of the project.

61 Bill Nichols, "The Voice of Documentary," Film Quarterly 36, no. 3 (April 1983): 17-30, doi: 10.2307/3697347, 18. 


\section{A. Portraits}

As Allan Sekula discusses in his writing, The Body and the Archive, portrait photography can either function as "repressive" or "honorific." 62 I considered this as I approached the portraits for this project. In the United States, photographs have actively played a role in the oppression of immigrants. Considering this, I was careful to avoid any resemblance to an institutional image.

I made the portraits of Juana and Samuel in the sanctuary of their churches. José's was made on the porch of the educational ministry where he is in sanctuary. I used a fulllength image in order to avoid the appearance of the "repressive" institutional photograph, which is usually framed around the head and shoulders. I also did not use a backdrop and ensured there was enough detail in the environment to place them. For each of the portraits I used the same gold reflector. I did so because I wanted the portraits to stand out from the rest of the images and to take on the lighting qualities of a baroque-era, religious painting (See Appendix, Figures 1,2,3). The depth-of-field I chose provides enough environmental detail to both place and keep the focus on the person pictured. Matching the depths of field also made the images more unified.

These portraits are meant to be "honorific", as Sekula delineated. ${ }^{63}$ One could argue that there are irresponsible uses for this type of image. If one employed this strategy to create

\footnotetext{
62 Allan Sekula, "The Body and the Archive." October 39 (Winter, 1986): 3-64, doi:10.2307/778312, 7.

63 Allan Sekula, "The Body and the Archive," October 39 (Winter, 1986): 3-64, doi:10.2307/778312, 7.
} 
honorific imagery of an individual already in a position of power, especially one engaging in repressive behavior, I would criticize their ethics. In the case of these portraits I certainly ran the risk of glamorizing this condition, especially in my choice of painterly lighting. In documentary photography, an image could drift from honorific to romanticized rather easily. However, I see these portraits as helping to strike a balance between the unavoidable representation of victimhood and the consistent, yet less-visible state of defiance and protest in which these people are constantly engaged. This aspect of sanctuary is critical to understanding it, but is underrepresented in imagery on the topic. In making the portraits, I sought to create images with a specific conceptual function that one would not normally see in the representation of sanctuary. I intended for these images to have a presence. In this and similar situations, so often the person implicated is made to be unimportant in comparison to the political conditions. The portraits are meant to be a declaration of each participant's individuality. 


\section{B. Still Imagery}

The still imagery makes up the core of the project. It consists of select moments from the time I spent with my participants, and details of the spaces in which they are living in refuge. The images are not shot in a traditional photojournalistic style, although they are descriptive in nature.

In this project I relied on symbolic details to hint at various themes that came up in my discussions with participants. A small number of these pictures made the edit and I slipped them in because, for the careful observer, they serve to destabilize the default media narrative. This default sanctuary narrative is consistent with the standard drama triangle, consisting of victim, hero and villain. This is consistently the basis for news stories about sanctuary, with the immigrant, the church and ICE being the victim, hero and villain respectively. This does make for an easy writeup and, for the average reader, an easy consumption. It falls, however, exceptionally short of telling the story.

For example, I would consistently hear stories of excessive control on the part of sanctuary churches. This included restricting movement should they want to leave. It is rare that an individual would want to leave their sanctuary church but there were several people whose churches did not allow them to visit the summit in Durham. Some of those who did attend still experienced resistance from their church. It is certainly a risk to leave the sanctuary, but as one local activist who was herself an undocumented woman commented-it is pure support these people need, not further control. I hinted at this in 
several images. One such image shows a cross outside of the basement of a church (See Appendix, Figure 4). By using a strong angle, the cross looms forebodingly in the image; beneath the cross a motion detector resembling a surveillance apparatus is fixed. The disquieting appearance of the image coupled with its reference to supervision and control is meant to insinuate the unwanted pressure exerted by certain churches. Furthermore, it applies to the augmented and persistent state supervision to which people in sanctuary and undocumented activists are subjected.

Another example of an image using such symbolism shows José kneeling in prayer during a service in his sanctuary (See Appendix, Figure 5). Due to the fairly normal appearance of these spaces, it was difficult to cast them as the detention spaces that they are. They bear little resemblance to the cold institutional buildings which normally function this way. In this image, the slats of the chair's back appear like the bars of a prison cell as he prays behind them. The image also speaks to the themes of isolation and confinement core to the project. 64

Photographs of sanctuary are almost always the same. They show tears. They show prayer. They show the basic acts of living. These are not entirely absent from my work; they are indeed a fact of these situations. But this repetition fails to say something deeper about the conditions of this life. The still imagery element of this project is the space where I felt comfortable commenting from my position; it's where my voice as a storyteller and the

\footnotetext{
${ }^{64}$ Both Figures 4 and 5 were removed when I was doing the final layout in the gallery. While I still believe images like these are important to the project in other forms (book, web, etc.), they felt redundant and overly assertive in the gallery space. Additionally, I felt that the other themes as seen in Figure 6 and 7, were more important to the experience of the project in a gallery space as opposed to a publication.
} 
core themes of the project are most evident. Windows appear frequently in the edit, referencing the dichotomy of inside versus outside (See Appendix, Figure 6). The use of tight framing, verticals and cramped spaces all speak to the confinement and isolation of the experience. Images of photographs of family members show both their existence and their absence (See Appendix, Figure 7). These images also memorialize a former life, one that for the time being has been lost.

Commentary on sanctuary is the core purpose of the still imagery. The larger issues of being undocumented, the position of immigrants in society and the experience of migration were topics critical to the narrative but where I felt a need to more actively seek a representational balance. It is the time-based element of the project where these issues are discussed. 


\section{Audio and Video}

The time-based element of the project filled an important gap in the story. It satisfied the need for directness. Photography is rarely straightforward. It is layered with subjectivity both in its creation and its observation. This is why it is my chosen medium. But it cannot clearly say everything it needs to. Audio is direct. I have always been inspired by StoryCorps, an American oral history project with "an intense focus on the collecting, sharing, and preserving of people's stories." 65 It was in the spirit of StoryCorps that I approached the audio. Using interviews, I brought the voices of my participants into the project. They told the stories that only they could: the stories of their childhood, their journeys and their private moments, stories that needed to be unambiguous. Photographs are absolutely capable of telling stories of the past. They do it through innuendo and interpretation, leaving them open to ambiguity. The histories and opinions of my participants needed to be laid out squarely. The video is meant to accomplish that.

In the inclusion of this element of the project, I sought a balance between my voice as a creator (found primarily in the still images and wall text) and the voices of the participants. Additionally, I edited my own voice into several of the oral histories in order to declare my responsibility to the piece and establish these recordings as conversations. I will refer to Linda Alcoff once again: "We should strive to create whenever possible the conditions for dialogue and the practice of speaking with and to rather than speaking for others." 66 It was

\footnotetext{
65 StoryCorps, "About StoryCorps," StoryCorps, accessed May 21, 2019, https://storycorps.org/about/.

66 Linda Alcoff, "The Problem of Speaking for Others," Cultural Critique, no. 20, (1991): 5-32, doi: 10.2307/1354221, 23.
} 
through the integration of lightly-edited oral histories that I endeavored to create these conditions. 


\section{Audio}

The time-based portion of Shut Away is founded on the audio. I had a list of interview questions that I asked each of my participants but I treated the interviews like conversations as much as possible. The most valuable pieces of audio were the result of spontaneous questions that emerged from their answers. Shut Away does not reference the current administration outside of the audio. While I did not want to turn the project into a critique of the current White House, I could not leave it entirely unstated. In one of José's stories he says "...we definitely have a group that has taken advantage of this new presidency and come out with hate against immigrants and people of color. Well we say that the responsibility lies at the top because the President has that spirit of racism." ${ }^{\prime 67}$ This way, the effect that the current administration is having on the immigrant community and society is told by someone deeply impacted.

I wanted the stories to be as authentic as possible; the breath, the fillers, pauses, laughs or chokes needed to remain intact. Therefore I recorded the audio without a camera present as I believe cameras often affect the authenticity of the interview. The voice is the keystone of this component of the project and its qualities are as important to me as the words. As Adriana Cavarero describes in her essay The Vocal Body, "...the voice not only plays an essential role but influences the very structure of the word itself and, therefore, of language, which now bends to the rhythmic and sonorous demands of vocality." 68 The

\footnotetext{
67 José Chicas, "Shut Away," interview by author, July 22, 2019.

68 Adriana Cavarero, "The Vocal Body: Extract from A Philosophical Encyclopedia of the Body," translated by Matt Langione, Qui Parle 21, no. 1 (Fall 2012): 71-83, doi:10.5250/quiparle.21.1.0071, 78.
} 
specific aural signature of the individual is of vital importance, as the qualities of a voice influence the meaning and interpretation of the words it speaks. In the work's presentation I chose to edit the interviews into a single-channel video installation. This allowed me to play the audio on speakers throughout the gallery. This demands that the audience feels what the speaker is saying, as sound has an assertive quality not found in visual media. In The Affective Power of Sound, Siobhan McHugh states that "...sound envelops us, pouring into us, whether we want it to or not, including us, involving us." 69 The affective responses to retelling these stories, as listed above, are detectable regardless of spoken language as they are precognitive corporeal phenomena. When played throughout the gallery, this affect is transferred to the audience. In the conclusion of her essay McHugh asserts,

Oral history that reveals a narrator's strong feelings and emotions will engender strong affective resonances in listeners and thus be retained. If well crafted as storytelling through sound, using sounds own affective power, oral history...can be elevated to an art form that can move, inform, and delight its audience. 70

Filling the space with the voice of my participants also impacts the reception of the still images themselves. The voice partially removes the audience from the formality of the gallery space and moves them closer to the raw experience of the sanctuary space. Inherently, photographs do not have the same immersive possibilities that video does. The introduction of audio to the space, regardless of the size and prevalence of the video monitor, augments the immersive qualities of the exhibition in general, including the effects of the still images.

\footnotetext{
69 Siobhán McHugh, "The Affective Power of Sound: Oral History on Radio," The Oral History Review 39, no. 2 (Summer 2012): 187-206, doi:10.1093/ohr/ohs092, 188.

70 McHugh, "The Affective Power of Sound," 206.
} 


\section{Video}

Selecting a form for the visual aspect of the video installation was difficult. Personally, I would have been inclined to play the audio interviews in the space with the still imagery and not have a video element.71 However, seeing as this presentation was in Toronto and the interviews are in Spanish, I needed to have a place to display subtitles. This presented the danger of trying to insert video into the project just for this purpose and, as a result, not bringing any additional nuance to the project. After moving through several different ideas, what I finally decided on was the video portrait (Appendix, Figures 8, 9). While the voice has affective power, the presence of a person to associate with it strengthens the emotional connection made by the audience. The audience's ability to visually experience the breath and mannerisms of the participants further augments that connection.

In these portraits there is a tension between the participant and the camera. I was not in the room during the making of the video portraits. I explained to my participants what we were going to do and how I would employ the results. I would then set up the camera in the room and tell them I would return in ten minutes. Over the course of the ten minutes, José and Juana both got restless and frustrated with having to sit there, as anyone would. I felt that this tension would be palpable and help illustrate the concepts of confinement and enclosure central to the project. The key themes in the project, like that of inside versus outside, also appear throughout the installation. During one oral history Juana says, "Sometimes I just stay looking out the window. I watch the animals pass by, there are a lot of deer, and little birds. I see these animals that move freely and we're not able to have

71 I would, in that case, provide written transcripts for those with hearing impairment. 
that freedom, it's very hard."72 In the video portrait Juana is sitting by a window, emphasizing this connection.

In the case of Samuel's portrait, something equally important but much different is shown (Appendix, Figure 10). That is absence. I created the video portraits over the winter production period and at that time, Samuel had already been arrested and deported by ICE. The chair that I placed in the center of his room in the basement was the chair that he sat in every Sunday at Mass. Some children from the congregation had made a sign that read "Samuel's Seat, Keep Praying" and taped it to the back of his chair. The sign is visible in the video portrait and further illustrates absence and indicates a distressing past event. The chair remains empty every Sunday during the service. On the table to the right of the chair are several boxes packed with items hanging out, and a stack of books. Samuel's space, devoid of life, with signs reminiscent of moving day, display something vital to the project, especially when compared with the other video portraits. At one point in the audio interview, after describing missing his son's two previous graduations, Samuel says, "I just hope that when he's leaving college I can accompany him to his graduation, that I'm not in some immigration process..." ${ }^{73}$ Coupled with the vacant image, this description of his forced absence from his son's life has even more impact and it shows the sense of immediacy inherent to this issue.

The combination of the oral histories and video portraits create what I believe to be a powerful method of storytelling. They allow the viewer to connect to those pictured

\footnotetext{
72 Juana Luz Tobar Ortega, "Shut Away," interview by author, August 4, 2018.

73 Samuel Oliver Bruno, "Shut Away," interview by author, July 17, 2018.
} 
through both sight and sound and in disconnecting the two, the comfort of the participant during production is prioritized. Thus the story is told with clarity. 


\section{Presentation}

The thesis exhibition for this project took place in the Student Gallery at the Ryerson Image Centre between June $9^{\text {th }}$ and August $4^{\text {th }}, 2019$. In the presentation of this work, I had three main goals. The first was for the context of the project and the identities of José, Juana and Samuel to be clear. The second was to create some tightness, both physically and visually, in an open space. The third was to bring the emotional urgency of the topic into the gallery by creating affect via the time-based component.

At the front of the gallery I placed a six-foot-wide floating wall. The purpose of the wall was to create an obstacle and to give a feeling of confinement. While a small space, the student gallery feels open and spacious because of the glass wall as one enters. This feeling would be at odds with the claustrophobic nature of the project. Additionally, I wanted to prevent the visitor from viewing the work without entering the gallery, thereby avoiding the audio. On the front of the wall I placed the artist statement. I wanted the statement to be read before viewing the show, as I felt the work needed to be contextualized. The statement was divided into two columns: one written in Spanish, the other in English. On the reverse side of the wall, I placed a monitor which showed the video installation. The audio played through speakers throughout the gallery. In this setting, many of those visiting the exhibition would not understand the audio, as my participants are speaking in Spanish. However, as stated in the previous section, this still transmits the affective qualities of the voice. 
Each wall was dedicated to one participant. I placed their portrait near the middle of the wall and surrounded them with images taken in their sanctuary spaces. Initially, I had planned to display the portraits separate from the other images, which would be combined into one sequence. I grew increasingly uncomfortable, however, with the concept of blending their narratives; this seemed antithetical to the message of the work. On each wall there was a small placard which displayed the name of the participant as well as their home country, location in sanctuary and time they have spent there. This detail was very important as it anchored the images to a specific individual.

There were two different sizes of images. The portraits I printed large, $24^{\prime \prime} \times 36^{\prime \prime}$. the rest of the images I printed at $12^{\prime \prime} \times 18^{\prime \prime}$. I did this so that the portraits, which were already visually distinct from the other images, would be further elevated. For the size of the space I chose to hang a large number of images, as I wanted the walls to reflect the feeling of confinement that is core to the project. The first and last images in the sequence are exteriors of the sanctuary churches. I thought that they served as good bookends for the sequence as one would enter and exit the project on an exterior view. This spoke to the theme of inside versus. outside and that of confinement and enclosure.

By playing the audio throughout the gallery and printing the portraits significantly larger, I intended to elevate the voices and presence of the participants in the installation. This was balanced against my commentary on the experience seen through the wall text and still imagery. Combined, with the introduction of confinement via the floating wall and density of images, I felt that this would be both a creative and appropriate arrangement for the 
exhibition.

Going forward, I would like to install the images in the churches where they were made so that they can be experienced by the participants, their families and the community. I will certainly be speaking with contacts in activism to explore its potential uses and would like to create a publication so that a physical iteration of the project can be distributed. And of course, I intend to pursue the work's publication on an appropriate national news media website, in the hopes that these specific stories can reach a wider audience, especially the other people living in sanctuary across the United States. 


\section{Documentary Relevance}

In the broadest sense Shut Away is a project about immigration, a topic whose relevance is self-evident. Arguably the most politically impactful image of 2018 was photojournalist John Moore's image of a young Honduran girl crying at the feet of her mother and a US Border Patrol agent. The image was written about by every major news outlet in the US and even solicited tweets from senators on both sides of the aisle, the White House press secretary and the son of the President. ${ }^{74}$ It was also the "cover" image for a Facebook fundraising campaign by the immigrant's rights organization RAICES, the most successful campaign ever of its kind. ${ }^{75}$ John Moore also received the Lucie Foundation's inaugural Impact Award for this image in the fall of $2018 .{ }^{76}$

There is an abundance of documentary work on the topic of immigration in the Americas. Many of these works focus on the US-Mexico border. Photographers and filmmakers like Dorothea Lange, Chantal Akerman, Alex Webb and Tomas Van Houtryve have created work on this subject. Many projects focus on interior immigration issues as well, from the work of Jacob Riis nearly 130 years ago to that of present-day photojournalists such as John Moore.

\footnotetext{
74 Sarah Sanders, "It's Shameful That Dems..." Twitter, June 22, 2018, https://twitter.com/PressSec/status/1010158215068340229.

75 Charlotte Wilner, and David Wilner, "Reunite an Immigrant Parent with Their Child," Facebook, accessed October 16, 2018, https://www.facebook.com/donate/490507544717085/.

76 The Lucie Awards, "John Moore," Lucie Foundation, accessed October 16, 2018, http://www.lucies.org/honorees/john-moore/.
} 
Despite this multitude of applicable work, in order to situate Shut Away, I will compare and contrast it with a single project on the topic of immigration: Melanie Friend's Border Country. I will then situate myself as a photographer within the broader philosophies and traditions of the medium. 


\section{A Unique Representation of Immigration}

Melanie Friend's Border Country is a project that relates to Shut Away both thematically and creatively. ${ }^{77}$ Friend has been active as a photographer since the mid 80's. She started as a freelance photojournalist and writer before moving into radio and, later, long-form documentary projects. Friend currently teaches at University of Sussex in both the Photography program, and the Media, Film and Music program. Friend started utilizing audio interview in her practice with her work in Kosovo during the Milosevic era. ${ }^{78}$ This includes the project Homes and Gardens which depicted spaces that, despite being peaceful in appearance, were sites of previous violence. She layered these images with audio testimony of said violent events from those who had been impacted. The project was shown at the Hasselblad Centre in Sweden in 2001. ${ }^{79}$ Border Country, which tells the stories of refugees in British detention centers awaiting deportation, also used this format. 80

Border Country combines the audio interviews of detainees in a UK Immigrant Removal Centre with photographs of empty institutional spaces at the site. Included among these spaces are visiting rooms, recreational areas, prayer rooms as well as fences, walls and security structures (See Figures 11, 12, 13). In Border Country, Friend impressively

\footnotetext{
77 Melanie Friend, and Karen Downey, Border Country, Belfast: Belfast Exposed Gallery, 2007.

78 Melanie Friend, "About," Melanie Friend, accessed April 08, 2019, https://melaniefriend.com/about/.

79 Melanie Friend, "About," Melanie Friend, accessed April 08, 2019, https://melaniefriend.com/about/.

80 Melanie Friend, "Representing Immigrant Detainees: The Juxtaposition of Image and Sound in 'Border Country,'" Forum: Qualitative Social Research 33, no. 11 (2010): 1-25, http://www.qualitative-research.net/index.php/fqs/article/view/1484/3007, 7.
} 
navigated the restrictive constraints of immigration institutions to create a project that makes firm statements about the effects of detention, the immigration system and the representation of migrants and asylum seekers. 


\section{Shut Away in Comparison}

While differing slightly in topic and substantially in style, Melanie Friend's Border Country serves as a useful comparison to Shut Away in its use of the voice in combination with still imagery. In terms of the audio recordings in my project, the voice itself is as important to me as the words. Friend expresses a similar sentiment in her description of Border Country, calling the voice an "emotional force." ${ }^{11}$ In Friend's essay Representing Immigration Detainees: The Juxtaposition of Image and Sound in "Border Country," she states, "I hoped that in the exhibition, the voices would draw in the viewer: using the medium of sound can also effect a more emotional response and lead to greater involvement." 82 This is a hope I shared for my own exhibition as I have previously discussed. In the use of the voice both in and out of the gallery, Border Country and Shut Away seem closely aligned in both desired effect and rationale.

Within the still imagery, the two projects differ significantly. Most obviously, all the images in Border Country are devoid of people. This was partly due to the agreements she made with the institutions and subjects but it was also a creative choice..$^{83}$ Initially the project had included portraits of whichever interviewees would consent to having one made. In the end, though, Friend felt that they were visually inconsistent with the other images, and she was concerned about their representational characteristics and for the safety of her

\footnotetext{
81 Melanie Friend, "Border Country," Melanie Friend, accessed April 08, 2019, https://melaniefriend.com/border-country.

82 Melanie Friend, "Representing Immigrant Detainees," 6.

83 Melanie Friend, "Border Country," Melanie Friend, accessed April 08, 2019, https://melaniefriend.com/border-country.
} 
subjects. 84 My project, on the other hand, shows people frequently in the images. Additionally, each of my participants has a portrait as part of the project. In discussing her choice to omit the portraits, Friend noted that "The formal style of the portraiture, with the individual standing within a tight institutional frame, back to the wall, risked objectification by the viewer or perhaps the detainee being viewed as a one-dimensional victim." ${ }^{85}$ From the start this was exactly the type of image I was attempting not only to avoid but to actively work against. Because of my unrestricted access to the spaces and the autonomy my participants had within them, I feel I was able to achieve this. Friend was not afforded this luxury so she made the choice to remove the portraits. In preserving only the unoccupied images, Friend creates significant tension between them and the emotionally rich audio. In her arrangement, placing the voice with images that show no people intensifies the feeling of absence befitting a project concerning immigrants facing deportation. In the case of my project, I feel that the inclusion of the portraits serves the important role of identifying the subject. I hope by fixing their stories and voices to their identities, the narratives will not fade into that of the generic immigrant.

By including in my project images that depict my participants, I am splitting up the emotional load of the work between those images and the audio interview. I believe that conceptually, Friend's strategy might be seen as more daring and developed, having a boldness that served the project well. Shut Away is certainly more traditional in its approach to the still imagery. In addition, it takes advantage of the photojournalistic crutch

\footnotetext{
${ }^{84}$ Melanie Friend, "Representing Immigrant Detainees," 6.

85 Melanie Friend, "Representing Immigrant Detainees," 14.
} 
of the dramatic in several of the compositions. The project does not create the same level of tension as Border Country since the emotion is spread throughout. That said, there are many images in the edit of Shut Away that, like Friend's work, are meant to show absence. Others are more deadpan depictions of the exteriors of the spaces (See Appendix, Figures $14,15)$. But while these are also detention spaces of a sort, they do not carry the same institutional vapidity as the spaces seen in Border Country.

In reading Friend's very detailed explanation of the creation of Border Country, it seems our projects had much in common at the outset. However, due to the limitations she was working within, her project shifted into something quite different stylistically. I believe these differences, as much as the similarities, make Border Country a valuable project for comparison and for positioning my own work within the documentary field. 


\section{Concerned Photography}

While I believe it is important to position Shut Away among specific works by other documentarians, I believe it's equally important for it to be contextualized within a philosophy of photography. In approaching this project, my inspiration was not the specific imagery of a creator, their choice of topic or their technique; I was inspired by the philosophy of concerned photography. This is true also of my arrival at non-fiction storytelling in general. It was my social and political concerns that brought me to use the medium in this way. Concerned photography's goal is to inform. As W. Eugene Smith famously stated, "Photography is a small voice, at best, but sometimes one photograph, or a group of them, can lure our sense of awareness." 86 The result of this awareness, hopefully, is action and resistance. That hope, though, is naive in its careless optimism.

Any of us, as storytellers, could be spending our time fully engaged in activism, organizing instead of making these works (although they are not entirely mutually exclusive). Photographers use these topics and their human subjects to spur their professional momentum within the documentary world. The line between altruism and exploitation can become a very fine one in this space. Additionally, projects under this heading have often had negative effects in their efforts to bring awareness to an issue. Many well-intentioned photographers have reinforced false and damaging narratives in the course of the medium's history.

86 W. Eugene Smith, Minamata, Tucson, AZ: University of Arizona Press, 1981, quoted in, John G. Morris, Get the Picture: A Personal History of Photojournalism, Chicago: University of Chicago, 2002, 279. 
Photography, though, is equally capable of unravelling such stereotypes. LaToya Ruby Frazier said about her work The Notion of Family, "I believe that visual, documented evidence has the ability to counter myths, omissions and distortions." ${ }^{87}$ I do hope, of course, that my images add to an accumulation of awareness that would eventually create change for these individuals. I am also bitterly aware of the inadequacy of photographs in creating much aside from awareness and compassion, which often do not mature into motivation and change. And as Susan Sontag has said, "Compassion is an unstable emotion. It needs to be translated into action, or it withers." 88 More often than not, socially-driven photography and film has created complacency in the same audience it was intended to rouse. To end her essay In, Around, and Afterthoughts (On Documentary Photography), Martha Rosler states that "...the common acceptance of the idea that documentary precedes, supplants, transcends, or cures full, substantive social activism is an indicator that we do not yet have a real documentary." 89

The concept of "the concerned photographer" may seem dated to some and narcissistic to others. It can certainly cause the focus to be shifted to the photographer and away from the subject. It is a charge, though, that I believe is important for storytellers to assume. After all there is plenty to be concerned about and everyone ought to be, but photography's role in activism and the world in general needs to be analyzed and resituated. Social documentary can evolve alongside the ever-changing media landscape instead of only inserting itself within it. This means slowing down and expanding practices

87 LaToya Ruby Frazier, The Notion of Family, New York: Aperture, 2016, 151.

88 Susan Sontag, Regarding the Pain of Others, New York: Farrar, Straus and Giroux, 2003, 101.

89 Martha Rosler, 3 Works, Halifax, N.S.: Press of the Nova Scotia College of Art and Design, 88. 
to adopt new modes of storytelling more suitable to topic, participant and constituency. In this evolution the emotional and narrative strength of the photo essays of the $20^{\text {th }}$ century can be folded into modern practice. By doing so, romanticization can be avoided while more complex and challenging work is created. This is what I attempted with Shut Away. I remain keenly aware, though, that without proper application, it could easily slip into the immeasurable collection of ineffectual social documentary; and that concerns me. The concerned photographer can and should be concerned about the function of photography. The form will be better for it. 


\section{Conclusion}

Two years have passed since uncertainty settled over the lives of José, Juana and Samuel. Now, at least two more will have to pass before it relents and their freedom is restored. Out of 10.7 million undocumented Americans, only fifty are shut away in churches. 90 Viewed statistically, it would seem insignificant. But this injustice, however limited, is akin to a larger system of habitual oppression and spurned responsibility. Two of those seen in this work fled violence that was created by the meddling of the United States government and it is past time for this government to assume responsibility for the lives that have been irreparably damaged by its actions. The purpose in denying these people their freedom is not reason, it is repression, and it is the duty of every citizen of the United States to acknowledge this.

As of June 2019, two of the lives seen in Shut Away look nearly identical and one of them looks entirely different: José is spending his twenty-fourth month in his Durham sanctuary; Juana, in her Greensboro sanctuary, is in the midst of her twenty-fifth month; but after spending eleven months in sanctuary, Samuel sits just over the southern border of the United States in Northern Mexico. Samuel is in his seventh month of distant separation from his family following his deportation. He is waiting for the chance to join them at home in North Carolina.

90 Bill Rodgers, "More Undocumented Immigrants Are Living in US Sanctuary Churches," VOA, January 29, 2019, https://www.voanews.com/a/more-undocumented-immigrants-are-living-in-us-sanctuary-churches-/ 4763198.html. 
As a non-fiction storyteller, I have grown immensely over the course of this project. Looking back, I would do many things differently should I be starting today. In the end, though, I am content with what I have created. With Shut Away, I strived to see beyond and work against the inadequate representations of the experience that are common in the media. I sought to embrace forms that I have not previously worked with in order to better tell the story. I aspired to create genuine relationships with my participants and I made it a priority. I believe that I have fulfilled those intentions. Above all, if this representation gives José, Juana and Samuel a sense of pride for the resistance they offer every day, I could ask for no more.

Word Count: 10,987 


\section{Appendix}
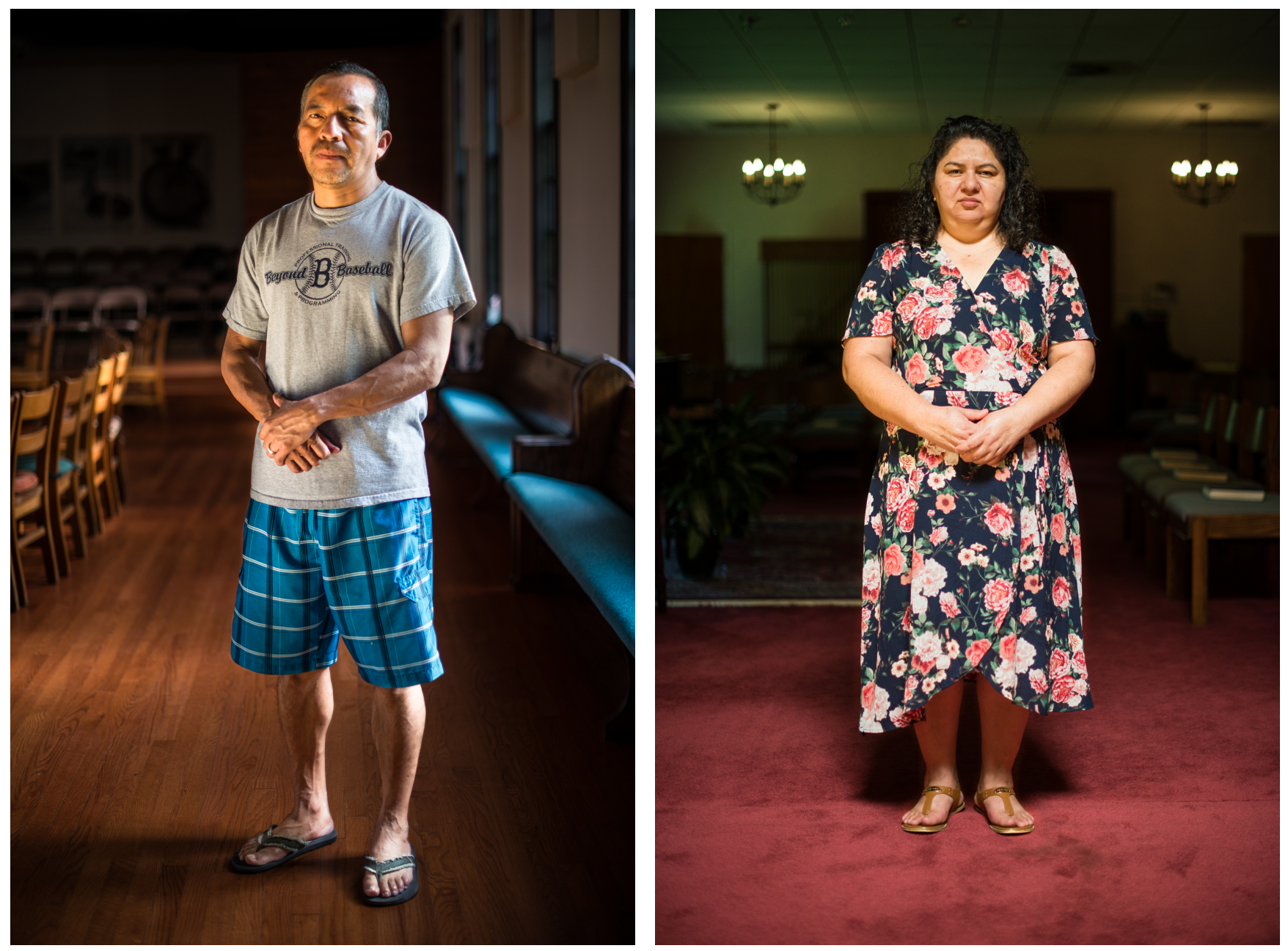

Figure 1:

Figure 2:

\section{Samuel Oliver-Bruno}

Samuel stands in the sanctuary of the church where he had been living in Durham, North Carolina, prior to his deportation. July, 2018.

\section{Juana Luz Tobar Ortega}

Juana stands in the sanctuary of the church where she has taken refuge in Greensboro, North Carolina. August, 2018. 

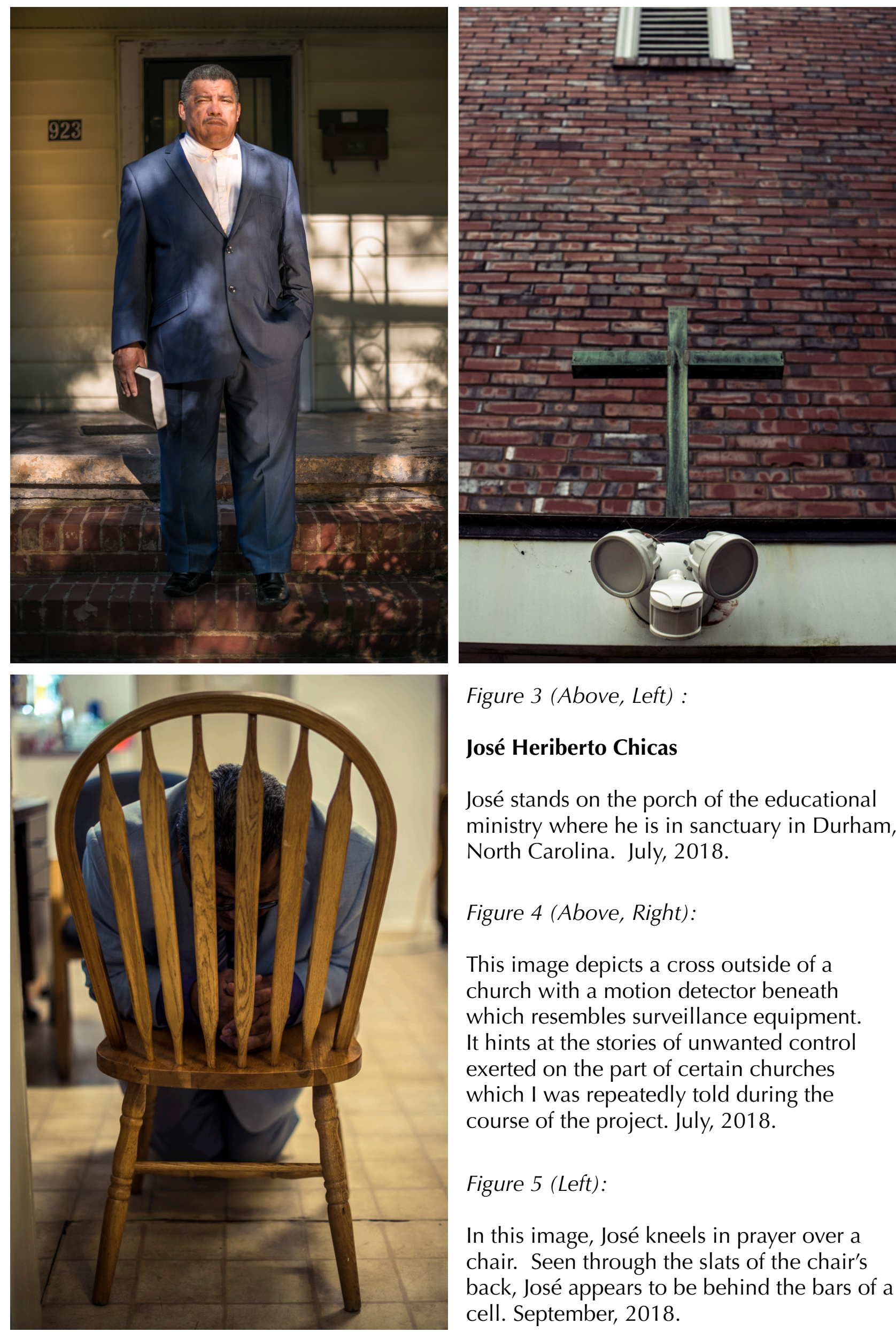

Figure 3 (Above, Left) :

\section{José Heriberto Chicas}

José stands on the porch of the educational ministry where he is in sanctuary in Durham, North Carolina. July, 2018.

Figure 4 (Above, Right):

This image depicts a cross outside of a church with a motion detector beneath which resembles surveillance equipment. It hints at the stories of unwanted control exerted on the part of certain churches which I was repeatedly told during the course of the project. July, 2018.

\section{Figure 5 (Left):}

In this image, José kneels in prayer over a chair. Seen through the slats of the chair's back, José appears to be behind the bars of a cell. September, 2018. 


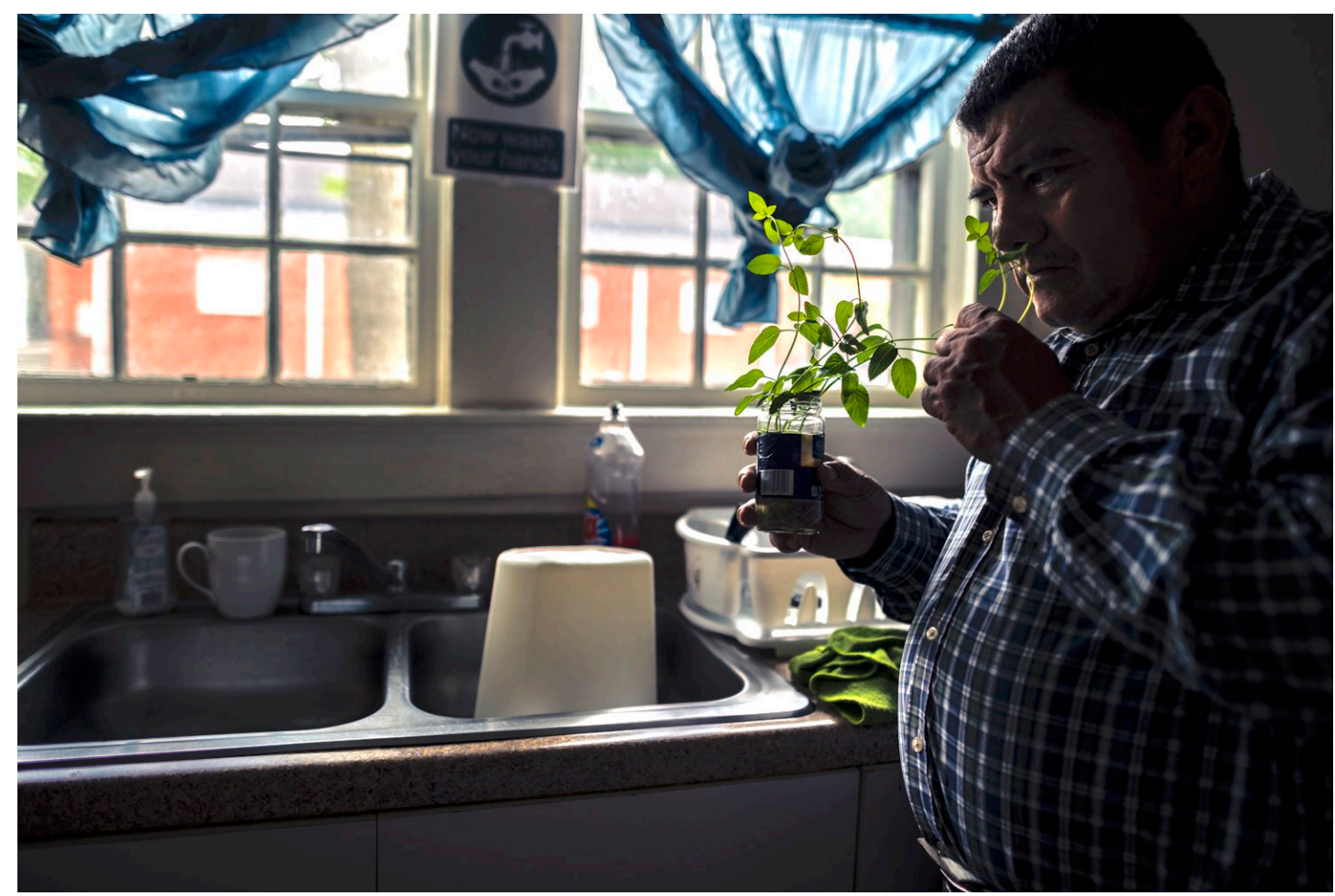

Figure 6: The repetition of windows throughout the edit illustrates one of the main themes of the project, the concept of inside versus outside. In many of the images, plants or flowers also appear on the "inside" of the image showing the presence of life on the inside and the desire for interaction with the outside. June, 2018.

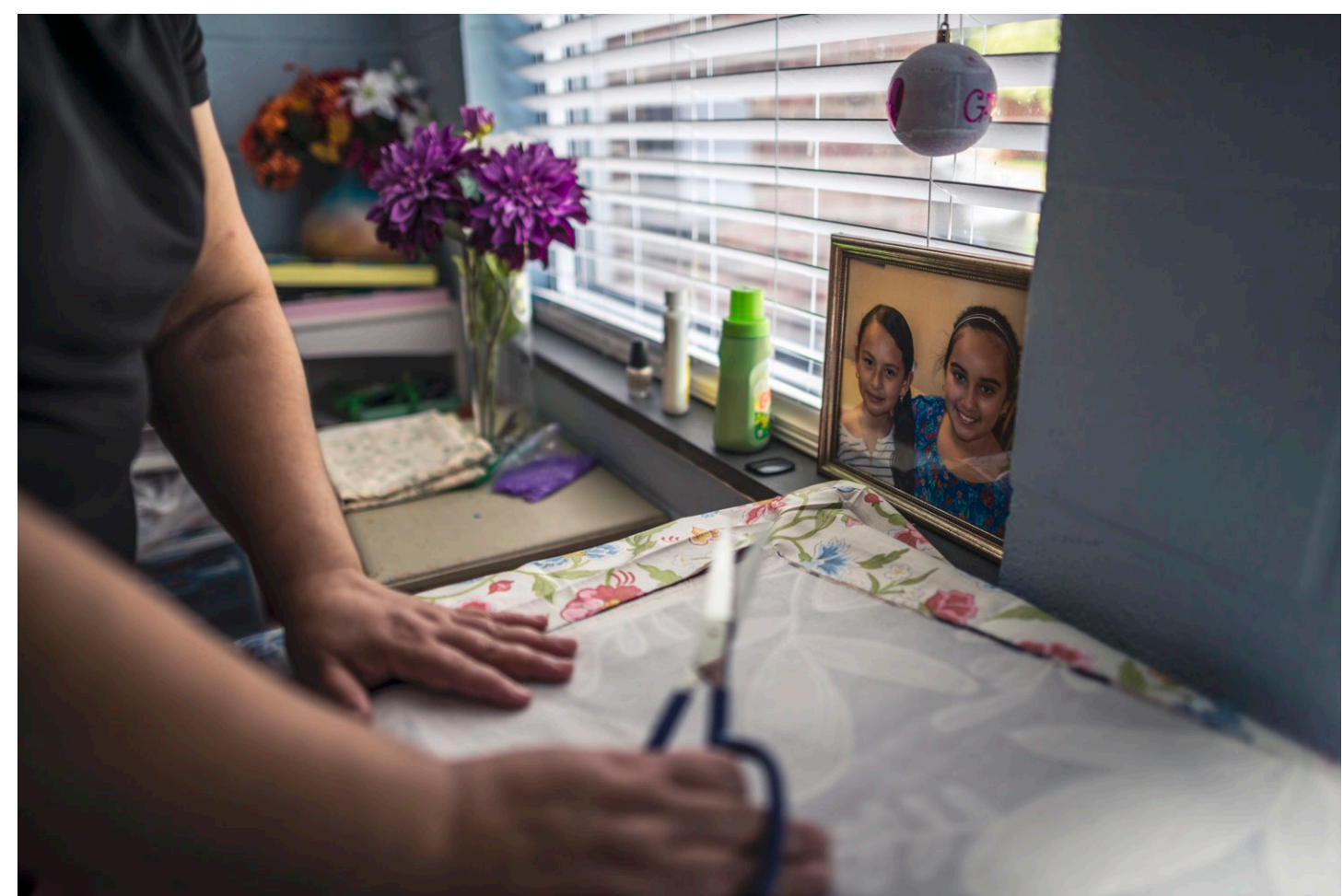

Figure 7: The presence of family photographs throughout the project shows their absence from the lives of the participants, the loneliness this causes and gives the sense of separation and isolation. August, 2018. 

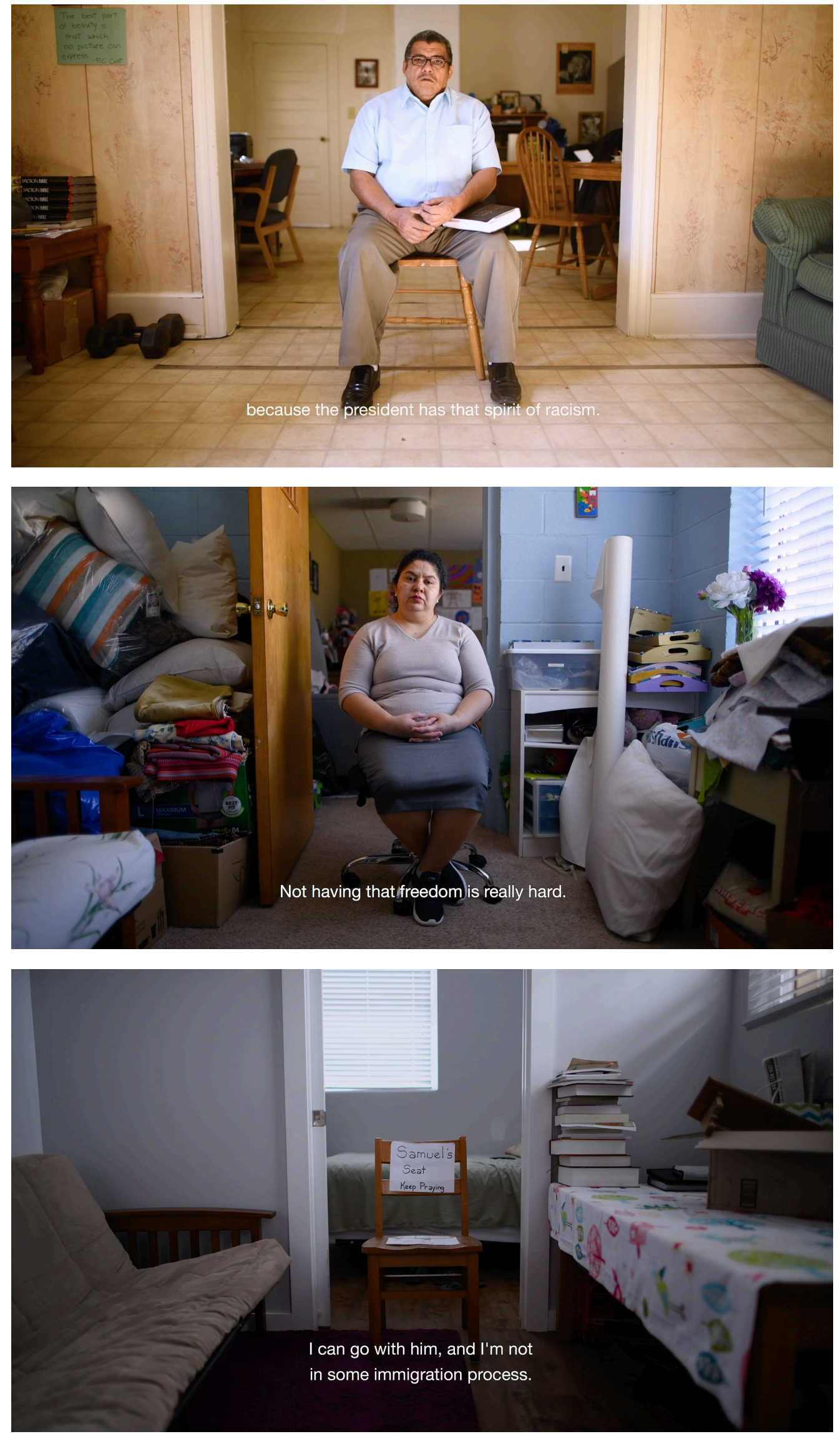

Figures 8, 9: These stills from the video portraits give a sense of the composition of the images and the expression of the participants. In these durational portraits, over time, José and Juana became bored and frustrated. These feelings are core to the experience, as they frequently communicated to me. December, 2018.
Figure 10: Samuel's video portrait shows the absence left by his deportation. This absence is also felt by those living in sanctuary and their families. The empty seat could stand in for those at their dinner tables at home. December, 2018. 

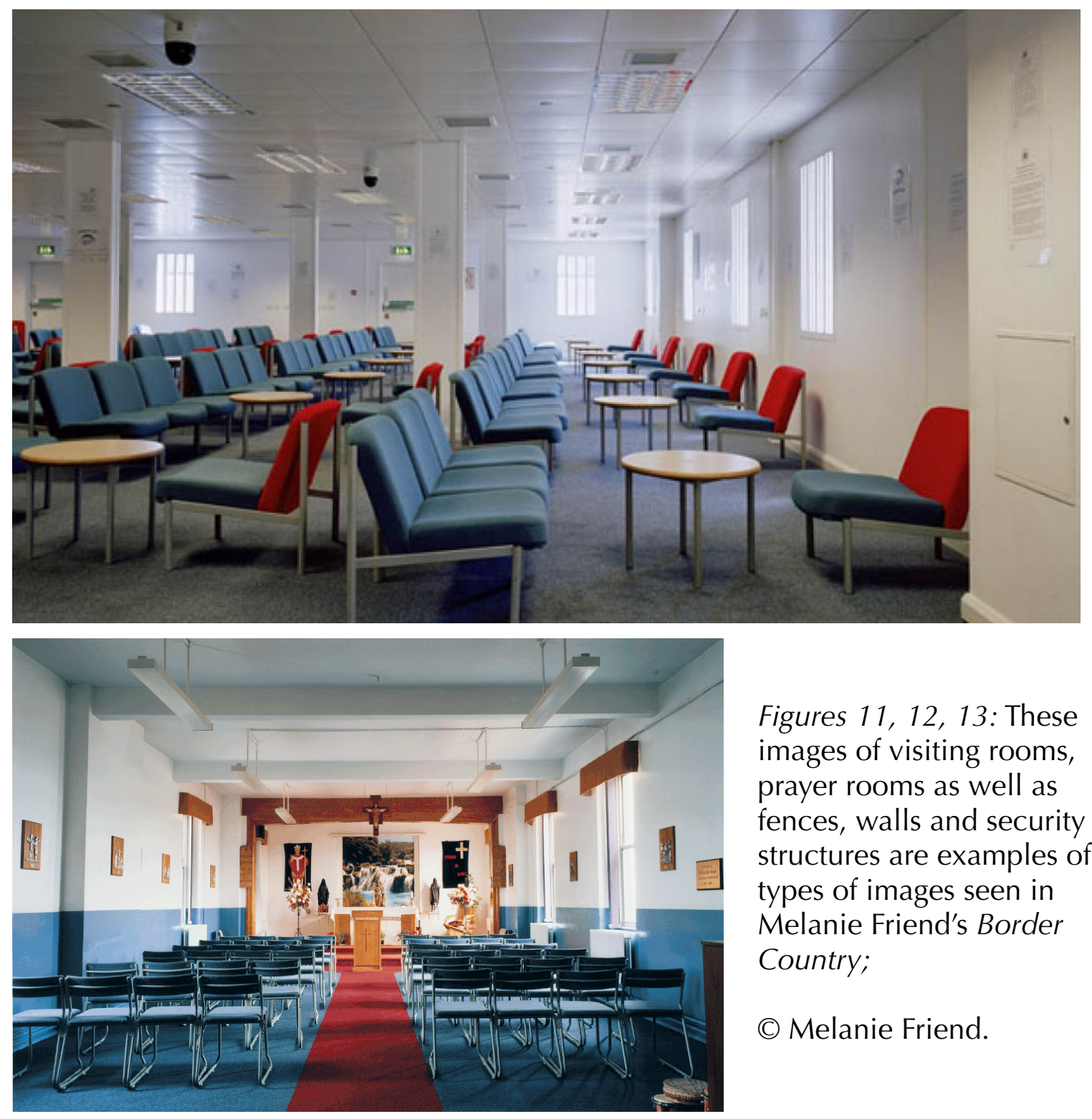

Figures 11, 12, 13: These images of visiting rooms, prayer rooms as well as fences, walls and security structures are examples of the types of images seen in Melanie Friend's Border Country;

(c) Melanie Friend.

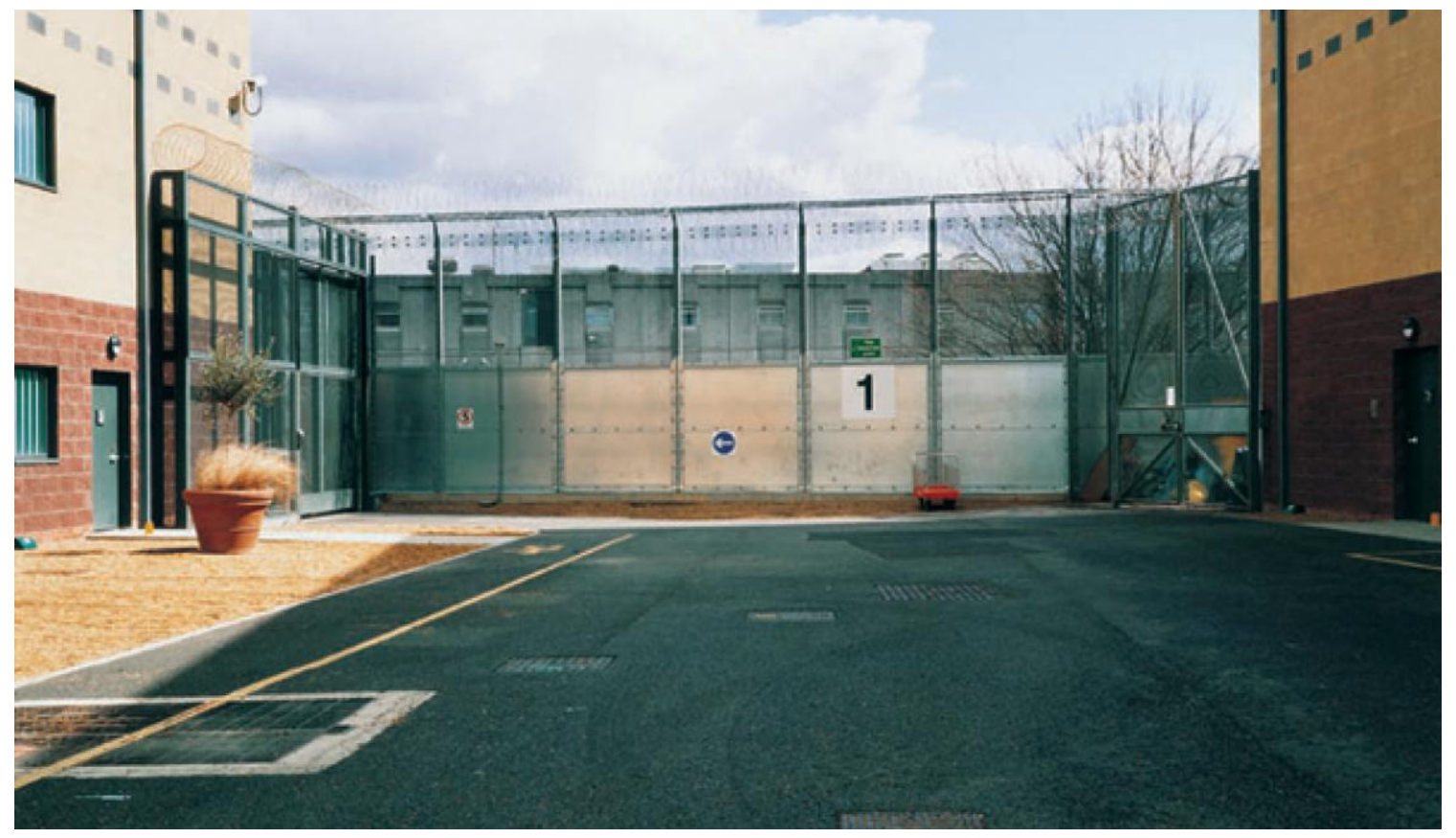



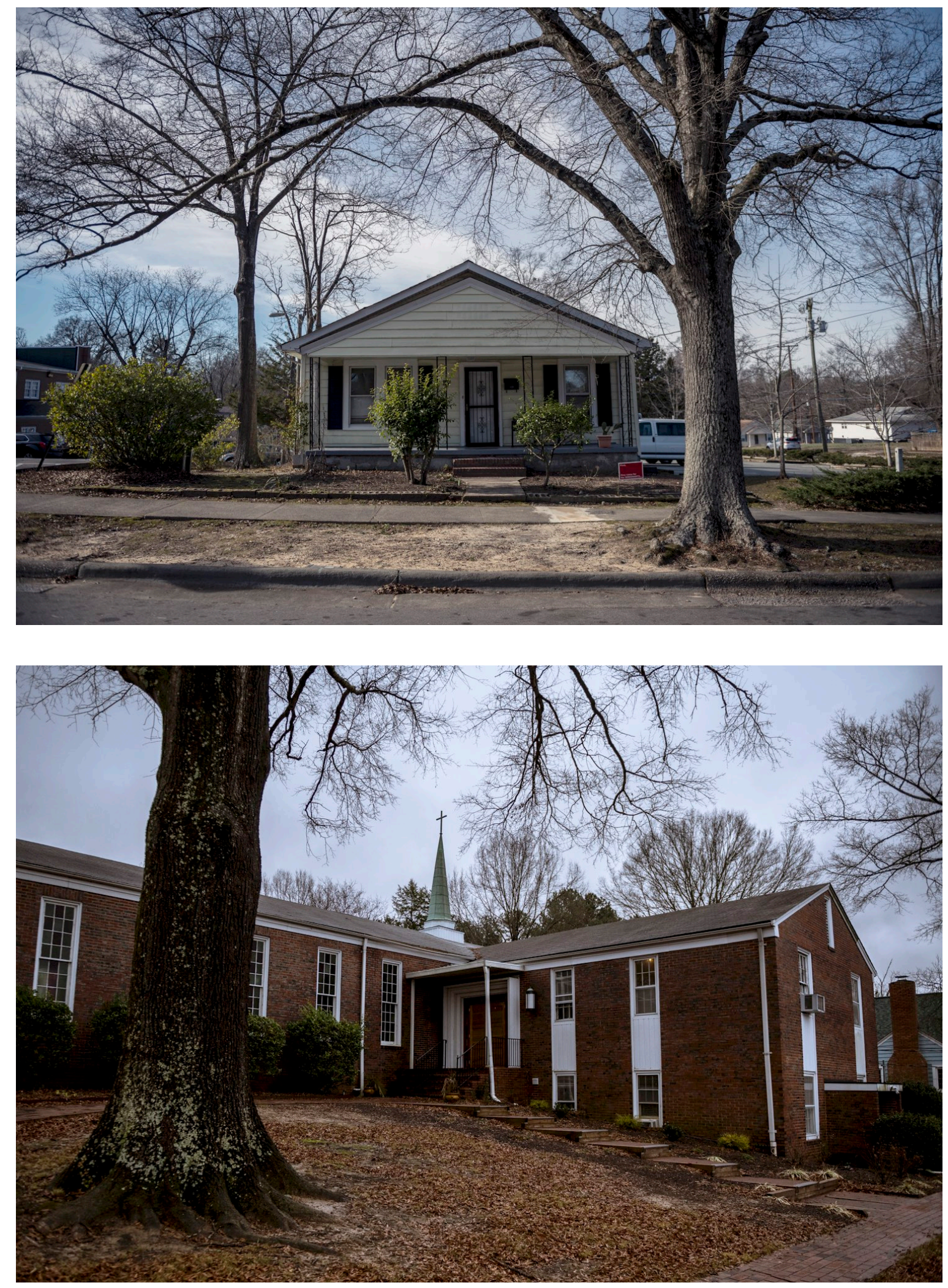

Figures 14, 15 : These more "deadpan" exteriors of the churches bear closer resemblance to Friend's exteriors of the detention centers. In the context of the exhibition, they were displayed as the first and last images in the sequence which contributed to the inside/outside dichotomy and to the feeling of being shut away. December 2018, December 2018. 


\section{Bibliography}

"The Mexican 1982 Debt Crisis." n.d. RaboResearch - Economic Research. Accessed December 13, 2018.

https://economics.rabobank.com/publications/2013/september/the-mexican-1982debt-crisis/.

"Timeline: Guatemala's Brutal Civil War." PBS. Last modified March 7, 2011. https://www.pbs.org/newshour/health/latin_america-jan-june11-timeline_03-07.

Alcoff, Linda. "The Problem of Speaking for Others." Cultural Critique, no. 20 (1991): 5-32., doi:10.2307/1354221.

Alerta Migratoria NC. "About." Alerta Migratoria NC. Accessed April 08, 2019. http://alertamigratoria.org/about/.

Amaya, Hector. "Trump and the Scapegoating of Latinos." From The Square, November 21, 2016.

https://www.fromthesquare.org/trump-scapegoating-latinos/\#.XBLLkpNKjEY.

Benen, Steve. "Trump Takes Anti-Immigrant Fear-Mongering to an Alarming New Level." MSNBC, June 25, 2018.

http://www.msnbc.com/rachel-maddow-show/trump-takes-anti-immigrant-fearmongering-alarming-new-level.

Brick, Kate, A E Challinor, and Marc R Rosenblum. "Mexican and Central American Immigrants in the United States." Rep. Mexican and Central American Immigrants in the United States. Washington, DC: Migration Policy Institute, 2011.

Brown, Joel. "Immigration Activists Interrupt Rep. Price's Raleigh Town Hall." ABC11 Raleigh-Durham. July 20, 2018. April 08, 2019. https://abc11.com/immigration-activists-interrupt-rep-prices-raleigh-town-hall/ 3791260/.

Cavarero, Adriana. "The Vocal Body: Extract from A Philosophical Encyclopedia of the Body." Translated by Matt Langione. Qui Parle 21, no. 1 (Fall 2012): 71-83. doi: 10.5250/quiparle.21.1.0071.

Cepla, Zuzana. "Fact Sheet: U.S. Asylum Process." National Immigration Forum. January 10, 2019.

https://immigrationforum.org/article/fact-sheet-u-s-asylum-process/.

Chicas, José. "Shut Away." Interview by author. July 22, 2019. 
Cohn, D’Vera, Jeffrey S. Passel, and Ana Gonzalez-Barrera. "Immigration From Guatemala, Honduras, El Salvador Up." Hispanic Trends Project. June 04, 2018. https://www.pewhispanic.org/2017/12/07/rise-in-u-s-immigrants-from-el-salvadorguatemala-and-honduras-outpaces-growth-from-elsewhere/.

Cullather, Nicholas. Operation PBSUCCESS: the United States and Guatemala, 1952-1954. Washington, DC: History Staff, Center for the Study of Intelligence, Central Intelligence Agency, 1994.

ICE. n.d. Enforcement and Removal Operations. Enforcement and Removal Operations.

Feere, John. "Plenary Power: Should Judges Control U.S. Immigration Policy?" Center for Immigration Studies. Last modified February 25, 2009. https://www.cis.org/Report/Plenary-Power-Should-Judges-Control-US-ImmigrationPolicy.

Frazier, LaToya Ruby. The Notion of Family. New York: Aperture, 2016.

Friend, Melanie. "About." Melanie Friend. Accessed April 08, 2019. https://melaniefriend.com/about/.

Friend, Melanie. "Border Country." Melanie Friend. 2018. Accessed April 08, 2019. https://melaniefriend.com/border-country.

Friend, Melanie, and Karen Downey. Border Country. Belfast: Belfast Exposed Gallery, 2007.

Friend, Melanie. "Representing Immigrant Detainees: The Juxtaposition of Image and Sound in 'Border Country.'" Forum: Qualitative Social Research 33, no. 11 (2010): 1-25. http://www.qualitative-research.net/index.php/fqs/article/view/1484/3007.

Gass, Nick, Ben Schreckinger, Cate Martel, Adam Wren, Jack Shafer, Michael Grunwald, Thomas Wright, and Rich Lowry. 2015. "Trump's Immigration Plan: Mass Deportation." POLITICO. POLITICO. August 17, 2015. https://www.politico.com/story/2015/08/donald-trump-immigration-plan-121420.

Geiger, Abigail. "Key Findings about U.S. Immigrants." Pew Research Center. November 30, 2018. http://www.pewresearch.org/fact-tank/2018/11/30/key-findings-about-u-simmigrants/.

Goodman, Amy. "Mexican Immigrant Takes Refugee in Arizona Church." Democracy Now!, May 15, 2014. https://www.democracynow.org/2014/5/15/headlines/mexican_immigrant_takes_ 
refugee_in_arizona_church.

Hamilton, Donald R. "El Salvador in the 1980s: War by Other Means." CIWAG Case Studies. June, 2015.

http://digital-commons.usnwc.edu/ciwag-case-studies/5

Koestler, Fred L. "BRACERO PROGRAM." The Handbook of Texas Online, Texas State Historical Association (TSHA). Last modified June 12, 2010. https://tshaonline.org/handbook/online/articles/omb01.

Labrador, Rocio Cara, and Danielle Renwick. "Central America's Violent Northern Triangle." Council on Foreign Relations. Accessed December 13, 2018. https://www.cfr.org/backgrounder/central-americas-violent-northern-triangle.

Lind, Dara. "Family Separation Was New, but Trump's New Border Policy Is an Obama Throwback." Vox, June 21, 2018. https://www.vox.com/2018/6/21/17488458/obama-immigration-policy-familyseparation-border.

Lind, Dara. "Sanctuary Cities, Explained." Vox, March 8, 2018. https://www.vox.com/policy-and-politics/2018/3/8/17091984/sanctuary-cities-citystate-illegal-immigration-sessions.

Lind, Dara. "Trump Has a Long History of Fearmongering about Immigrant Murder." Vox, February 05, 2019. https://www.vox.com/2019/2/5/1 8213077/state-of-the-union-2019-trump-davidkilled-immigrant-family.

The Lucie Awards. "John Moore." Lucie Foundation. Accessed October 16, 2018. http://www.lucies.org/honorees/john-moore/.

Mchugh, Siobhán. "The Affective Power of Sound: Oral History on Radio." The Oral History Review 39, no. 2 (Summer 2012): 187-206. doi:10.1093/ohr/ohs092.

Medina, Jennifer. "Too Scared to Report Sexual Abuse. The Fear: Deportation." The New York Times, April 30, 2017. https://www.nytimes.com/2017/04/30/us/immigrants-deportation-sexualabuse.html.

Morris, John G. Get the Picture: A Personal History of Photojournalism. New York: University of Chicago, 2002.

Morton, John. "Enforcement Actions at or Focused on Sensitive Locations." Rep. Enforcement Actions at or Focused on Sensitive Locations. Immigration and Customs Enforcement. https://www.ice.gov/doclib/ero-outreach/pdf/10029.2-policy.pdf. 
Nichols, Bill. "The Voice of Documentary." Film Quarterly 36, no. 3 (April 1983): 17-30. doi:10.2307/3697347, 18.

Oliver-Bruno, Samuel. "Shut Away." Interview by author. July 17, 2018.

Orozco, Myrna, and Rev. Noel Andersen. "Sanctuary in the Age of Trump." Rep. Sanctuary in the Age of Trump. Church World Service. 2018. https://www.sanctuarynotdeportation.org/uploads/7/6/9/1/76912017/ sanctuary_in_the_age_of_trump_january_2018.pdf.

Parker, Laura. "143 Million People May Soon Become Climate Migrants." National Geographic, March 19, 2018. https:// news.nationalgeographic.com/2018/03/climate-migrants-report-world-bank$\mathrm{spd} /$.

Passel, Jeffrey S, and D'Vera Cohn. " U.S. Unauthorized Immigrant Total Dips to Lowest Level in a Decade." Rep.U.S. Unauthorized Immigrant Total Dips to Lowest Level in a Decade. Pew Research Center. 2018. file:///Users/pearsonripley/Downloads/Pew-Research-Center_U-S-UnauthorizedImmigrants-Total-Dips_2018-11-27.pdf.

Raphael, T. J. "'Sanctuary Cities' around the US Promise to Defy Trump's Threats." PJI, November 15, 2016. https://www.pri.org/stories/2016-11-15/sanctuary-cities-around-us-promise-defytrumps-threats.

Rodgers, Bill. "More Undocumented Immigrants Are Living in US Sanctuary Churches." VOA, January 29, 2019. https://www.voanews.com/a/more-undocumented-immigrants-are-living-in-ussanctuary-churches-/4763198.html.

Rosler, Martha. 3 Works. Halifax, Nova Scotia: Press of the Nova Scotia College of Art and Design, 2006.

Sanders, Sarah. "It's Shameful That Dems..." Twitter. June 22, 2018. https://twitter.com/PressSec/status/1010158215068340229.

Sekula, Allan. "The Body and the Archive." October 39 (Winter 1986): 3-64. doi: $10.2307 / 778312$.

Shear, Michael D., and Julia Hirschfeld Davis. 2018. "As Midterm Vote Nears, Trump Reprises a Favorite Message: Fear Immigrants." The New York Times, November 1, 2018. https://www.nytimes.com/2018/11/01/us/politics/trump-immigration.html. 
Sontag, Susan. Regarding the Pain of Others. New York: Farrar, Straus and Giroux, 2017.

Stillman, Sarah. "When Deportation Is a Death Sentence." The New Yorker, June 22, 2018.

https://www.newyorker.com/magazine/2018/01/15/when-deportation-is-a-deathsentence.

StoryCorps. "About StoryCorps." StoryCorps. Accessed May 21, 2019. https://storycorps.org/about/.

Sullivan, Kevin, and Mary Jordan. "In Central America, Reagan Remains A Polarizing Figure." The Washington Post, June 10, 2004. http://www.washingtonpost.com/wp-dyn/articles/A29546-2004Jun9.html.

Tsai, Robert L., Matt Stoller, Peter Canellos, and Jack Shafer. "Trump's Travel Ban Faces Fresh Legal Jeopardy." POLITICO Magazine, March 27, 2019. https://www.politico.com/magazine/story/2019/03/27/trump-travel-ban-lawsuitsupreme-court-unconstitutional-226103.

Thomson-DeVeaux, Amelia. "How The Citizenship Question Could Break The Census." FiveThirtyEight, April 23, 2019. https://fivethirtyeight.com/features/how-the-citizenship-question-could-break-thecensus/.

United Nations. "Intentional Homicide Victims | Statistics and Data." United Nations. Accessed December 13, 2018.

https://dataunodc.un.org/crime/intentional-homicide-victims.

United States. "1912. 8 U.S.C. 1326 -- Reentry After Deportation (Removal)." Department of Justice. 2018. Accessed September 19, 2018. https://www.justice.gov/jm/criminal-resource-manual-1912-8-usc-1326-reentryafter-deportation-removal.

United States. "Consideration of Deferred Action for Childhood Arrivals (DACA)." Department of Homeland Security. Accessed December 14, 2018. https://www.uscis.gov/archive/consideration-deferred-action-childhood-arrivalsdaca.

Van Ham, Lane. "Sanctuary Revisited: Central American Refugee Assistance in the History of Church-Based Immigrant Advocacy." Political Theology 10, no. 4 (2009): 621-45. https://doi.org/10.1558/poth.v10i4.621.

Vasquez, Tina. "Samuel Oliver-Bruno, Deported After an Immigration Appointment, in His Own Words." Rewire.News, December 14, 2018. https:// rewire.news/article/2018/12/14/samuel-oliver-bruno-deported-after-animmigration-appointment-in-his-own-words/. 
Wilner, Charlotte, and David Wilner. "Reunite an Immigrant Parent with Their Child." Facebook. Accessed October 16, 2018. https://www.facebook.com/donate/490507544717085/.

Yeoman, Barry. "ICE Puts Immigrants Into a Cruel Catch-22." The Nation, December 6, 2018.

https://www.thenation.com/article/ice-samuel-oliver-bruno-deportation/. 